\title{
SocArXiv
}

Preprint : October 8, 2021

URL/DOI GOES HERE

\section{The Character of Class: Self-Concept, Self-Control and Social Immobility}

\author{
Sophie Moullin \\ Princeton University
}

\begin{abstract}
The importance of "character" or non-cognitive skills to socio-economic success has received much interest from across the social sciences, and in policy. However, there is little clarity as to what the non-cognitive comprises, or how or for whom it contributes to socio-economic outcomes. I consider a range of measures of children's self-beliefs and behaviors, and of class reproduction, in the British Cohort Study, a representative sample of Britons born in 1970. Model-based factor analysis finds there is no general non-cognitive dimension to skills. Children's self-concept and teacher-ratings of their self-control form two distinct factors, with the latter in particular closely related to cognitive skill. Natural effect models find self-concept as well as self-control helps account for social immobility, the lower chances of attaining the middle class, and the (higher) professional-managerial class, for those from working-class, and non-elite backgrounds. Much, but not all, of the mediation role of character reflects its association with performance on cognitive tests. Non-cognitive factors thus matter to socio-economic outcomes, but in a way more consistent with Bourdieusian models of cultural capital than with economic conceptions of human capital.
\end{abstract}

Keywords: non-cognitive skills, social mobility, class, cultural capital, natural effects.

\section{Introduction}

The importance of a person's "character" to their socio-economic success has recently received much interest across the social sciences, and in public commentary and policy. (Heckman \& Kautz, 2013; Heckman et al., 2014; Reeves, 2014). Spurred by the interest of leading economists in "non-cognitive skills", or "character" as they also call it, studies rapidly accrued across the social sciences since the turn of twentieth century. While almost exclusively concluding that character matters, there remains little clarity as to what character or the non-cognitive comprises - or how and for whom it matters socio-economic outcomes. Most 
existing studies have assumed that there is a single non-cognitive dimension to skills that can be contrasted with cognitive skills. Many have also assumed that socio-economic attainment is a continuous, linear process, rather than categorical, asymmetric and interactive one. However, using different measures of non-cognitive skills, and different socio-economic samples, studies have yielded conflicting results. Newly published meta- and replication analysis challenges the importance of character in socio-economic success (Morris et al., 2021; Smithers et al., 2018; Watts et al., 2018).

Chicago economists Heckman and Rubinstein (2001) first highlighted non-cognitive skills, as a residual explanation for the higher wages of those who graduated high school, compared to those with a certificate of equivalent cognitive skills. The initial work, they acknowledged was "written in the spirit of dark matter in astrophysics; we have discovered a non-cognitive dimension without identifying any particular non-cognitive skill" (p.149). Defined against cognitive ability, the non-cognitive could refer to a wide, indeed as Joshi (2014) notes, potentially infinite number of factors. But measures of the non-cognitive, and assumptions as to its relationship to cognitive skills, reflect different theories, and yield different results.

Behavior problems have been central to the notion of poor 'character'. Using evidence from randomized control trials (RCTs) of home and school-based early childhood programs for lowincome families during the 1960s United States, Heckman with Pinto and Savelyev (2013), found a reduction in externalizing behavior problems accounted for a fifth of the positive effect of attending the Perry Preschool program on earnings in later life. But such effects in smallscale policy experiments targeted at the most disadvantaged families are, per a recent metaanalysis published in Nature, are rarely robust or generalizable (Smithers et al., 2018). What is more, re-analysis of the Perry Preschool data finds that its positive effect was specific to the most disadvantaged, of the low-income sample, and worked through cognitive skills (Xie et al., 2020). In nationally-representative samples, externalizing problem behaviors in children are, in early childhood, associated with cognitive development, and later educational attainment, but typically those behavioral problems internalized toward the self are not (McLeod \& Kaiser, 2004; Moilanen et al., 2010; Turney \& McLanahan, 2015). Parental and teacher reports of behavior problems do not correspond well, perhaps reflecting differences in children's behavior in different contexts (Dirks et al., 2012). Moreover, these behavioral measures are widely used to indicate mental health "disorders", rather than skills (Currie \& Stabile, 2006; McLeod \& Fettes, 2007).

Self-control, an umbrella construct including delay of gratification, task-persistence, attention, conscientious and the popular-psychology construct of "Grit", has been associated with socioeconomic attainment, conditional on background factors, including in twin samples (Duckworth et al., 2012; Duckworth \& Seligman, 2012; Moffitt et al., 2011). In fact, an analysis of skills at school entry, found that attention was the only non-cognitive skill at this age that consistent predicted subsequent academic attainment (Duncan et al., 2007). But even this association does not hold up to controls for cognitive skills, socio-economic origins, and gender (Credé et al., 2016; Watts et al., 2018). Self-control is called "cognitive control" by many psychologists, who stress its overlap with measures of intelligence (Malanchini et al., 2018; Mischel et al., 2011).

Self-concept measures beliefs, rather than observed behaviors. Most notably, using a latent scale of self-efficacy, the belief in one's control over one's life and self-esteem, belief in one's worth, measured in adolescence, Heckman, with Stixrud and Urzua (2006), found substantial positive effects for high school and college completion, for earnings, and for attaining white- 
collar occupations, conditional on other factors, in the US cohort born in the fifties and sixties. But the evidence for the effect of self-concept, like for self-control, on socio-economic attainment depends on assumptions about their independence from cognitive skills, and class contexts (Hitlin \& Johnson, 2015; James \& Amato, 2013; Mirowsky \& Ross, 2007; Ross \& Broh, 2000; Twenge \& Campbell, 2002; Yeager et al., 2019). Effects for non-cognitive skills on attainment tend to be greater when measured in adolescence or early adulthood, reflecting their mutual development with cognitive and educational performance - and widening gaps in them by social class origins (de Araujo \& Lagos, 2013; Hsin \& Xie, 2017; Lewis et al., 1999; Moilanen et al., 2010).

Regardless of the measure, non-cognitive factors have largely been imported into a human capital model of socio-economic attainment that assumes a linear role for individual skills. But the treatment of class origin, and gender, in models, and the generalization from particular samples, reflects different theories of socio-economic attainment - and yields different results. Findings for the effects of non-cognitive skills from either policy and laboratory experiments rarely generalize to representative, population-level samples (Morris et al., 2021; Smithers et al., 2018). Even within select minority and low-income samples, average effects conceal significant heterogeneity (Xie 2020). Some models show average effects of non-cognitive skills remain significant controlling for parental socio-economic status. Yet effects under the umbrella of self-control are rendered small, and often insignificant when social background is probably conditioned on (Shanahan et al., 2014; Watts et al., 2018). Further, while some studies leverage sibling or twin data to control for background factors, others find substantial sibling correlations, and heritability in non-cognitive factors (Anger \& Schnitzlein, 2016; Demange et al., 2021; Fletcher, 2013). Studies comparing cohorts suggest that the distribution of skills, and their role in accounting for socio-economic attainment, is dynamic: while skills in general do less to account for income, non-cognitive skills become slightly more important compared to cognitive skills between cohorts born in the 1950s and 1970s (Blanden et al., 2007). From the 1970s, inequality in non-cognitive skills by parental socio-economic status has grown in recent decades, has become more important to educational attainment (Attanasio et al., 2020; Mazumder, 2015).

The core linear, or "meritocratic", assumptions of the human capital model have been challenged by sociologists (Jackson \& Grusky, 2018). Class - as a qualitative, categorical difference in employment relations - continues to profoundly structure socio-economic attainment, even with the expansion of education, service-sector and managerial jobs (Breen, 2019; Goldthorpe, 2016). The higher professional-managerial class in particular exhibits a high degree of social closure (Laurison \& Friedman, 2016). Class structures not only the development of skills, but the degree to which they matter to a person's attainment. Much social immobility remains unexplained by cognitive skills, and although effort, as well as cognitive skill, predicts occupational attainment, attaining a higher class requires higher levels of each for people from lower class origins (Breen \& Goldthorpe, 1999). Jackson (2006) finds for that for working-class men born in the 1950s in Britain the chances of attaining the middle class were negatively affected by social "withdrawal" reported in childhood. But the effects for the major non-cognitive skills, and other categories of class attainment, and for women and more recent cohorts, have not been investigated.

The inconsistent nature of the literature means we should first ask, somewhat inductively, what does character comprise; is there a single, independent non-cognitive dimension of individual skills or abilities? Then, we should ask, without making strong prior linear assumptions, 
how and for whom does 'character' matter for socio-economic outcomes; does it, jointly and categorically, account for enduring patterns of social immobility?

I use the range of prospective measures of non-cognitive skills taken in mid-childhood in the British Cohort Study (BCS), and model-based factor analysis that allows factors to correlate, to show the structure, or covariance, of measures of individual skills or abilities. I then use the BCS's high-quality data on recent occupational attainment, and a series of natural effect models for mediation that allow for non-linear, categorical outcomes, and joint mediation, to show if and how these skills help account for social immobility.

This fuller, more inductive approach helps reconcile the conflicting conclusions as to the importance of character in socio-economic success. It finds that subjective self-concept, and well as teacher-assessed self-control assessed in mid-childhood does play a role in socio-economic outcomes. Together, they account for at least $25 \%$ of the negative effect of a working-class origin on the probability of attaining the middle class, or the (higher) professional-managerial class. But the role of such character is more consistent with the theory of cultural capital, than of human capital. Character is best thought of not as an individual, independent skill in a linear process of socio-economic attainment, but as a composite of cognitive-emotional and behavioral factors that, largely through their relation to cognitive test performance in childhood, contribute to social immobility. I begin with the theoretical and existing empirical case for character as a cultural, rather than human, capital: a mechanism of class reproduction.

\section{Background}

\section{Character as the performance of self in a social economy}

Most sociological theory would predict that character - as a role performed by a social actor, if not the distinctive mental and moral properties of an individual - influences socio-economic outcomes. What a person wants to know about another in his presence, Goffman (1959, p. 1) wrote, second only to "his general socio-economic status", is "his conception of self". The self is performed for an audience wanting to know and evaluate a character. The performance occurs "backstage" or inwardly, as well as "frontstage" and outwardly (Luiz Carlos Baptista et al., 2003). The self acts on itself as well as on other people and the environment (Gecas, 2001). The character that it communicates constructs the social situation.

The economic situation should be no different. Against the labor market as a neutral mechanism, the cultural sociology of the economy sees occupational and employment institutions as having their own character, or set of cultural, moral meanings (Alexander 2011). Productivity therefore depends in part on the fit the between the character of the economic relationship, and the character of the person. Following Zelizer (2012), we can see economic activities not only as embedded in social relations, but as social relations. Economic productivity, therefore, depends on the quality of the relations. Those more "relationally skilled", or able to match their culture, or character, to that of their occupation, or employment relation will be more productive, and so better rewarded socio-economically (Bandelj et al., 2012).

That said, for economic sociologists, the value of character, as of any skill, would not be inherent or universal (Tomaskovic-Devey \& Avent-Holt, 2019; Vallas, 1989). It would depend on the character of the particular socio-economic context - and the characteristics of the person. What is more, a sociological perspective would also expect that the character people 
act is differently scripted and practiced (and perhaps, differently interpreted) in different socio-economic contexts.

\section{Character as the habituated self in social reproduction}

The performance of self, as Hochschild (1979) extended Goffman, involves "deep acting". Regulating one's emotions and their expression, in line with a culture's "feeling rules" is a process involving mental and bodily effort (Hochschild, 2003). Such emotional labor is a significant part of many jobs, particularly in the growing service sectors (Wharton, 2009). Yet, feeling rules, Hochschild (1979, p. 551) speculated in an aside, are class-specific, and learnt early in life. As a result, "each class prepares its children to psychologically reproduce the class structure".

The psychological aspects to class reproduction are central to Bourdieu's project, and contained in the concept of "habitus". "Cultural capital" is easily mistaken as a non-cognitive dimension of human capital (Lareau \& Weininger, 2003). But Bourdieu's theory challenges human capital theory's assumptions as to how skills or characteristics develop - and how they affect socio-economic attainment. Character, it suggests, is not one dimension of an individual, inherently productive skill or human capital. Rather, it is an enduring way to think, feel, and act, based on childhood conditions, that tends to reproduce those conditions (Wacquant, 2016). Cultural capital rejects the idea of a separable cognitive or subjective aspect to a person. Instead, people's subjective evaluations and identifications are informed by objective probabilities, and others' assessments. Equally even seemingly-neutral, standardized forms of assessment, Bourdieu and Passeron (1990) argued, would reflect cultural conventions. The habitus fused the social and personal, the mental and bodily. A person's dispositions, personalities, or ways of thinking could change, but not without reference to their own past, or wider social conditions (Bourdieu \& Wacquant, 1992). Bourdieu's limited discussion of childhood, and the self as such, is a weakness of his work (Pugh, 2013; Skeggs, 2004b). But the habitus does assume the importance of childhood class conditions, and selfhood, in their reproduction () (Salgues 2018).

Cultural capital also rejects the idea of a neutral, inherently productive skill held by individuals. Instead, the economic value, and evaluation, of a person's cultural capital is dynamic and relational (Lamont, 2012). For Bourdieu, disaggregating productive from arbitrary factors, or statistical from taste-based discrimination, at the heart of the human capital project, would be a futile exercise. Cultural capital was part of what constituted social groups in categorical distinction from each other (Bourdieu, 1987). In particular, at the micro level, the performance of character constituted the distinctions of class (DiMaggio, 2012).

\section{Existing micro-level evidence for character as cultural capital}

Micro-level studies, ethnographic and experimental, lend support to the idea of character as cultural capital. In families with children aged 10, Lareau (2003) observes the very emphasis on cultivating children's character, as opposed to letting it naturally grow, as something that is a part of, and specific to, a higher class culture. Higher class parents' 'concerted cultivation' of their children's development, Lareau argues, leads to a 'sense of entitlement', while for working class children a 'natural growth' approach leads to a 'sense of constraint'. In schools with children at similar ages, Calarco (2014) observes children's expectations of being able 
to develop their skills, and their active engagement with their teachers, as part of a higherclass culture. Such cultural schema, she argues, are particularly important when behavioral expectations, or the nature of evaluations, are ambiguous. At occupational entry too, Rivera (Rivera, 2015) observes the importance of "cultural matching". Even among similarly qualified university graduates, the "fit" within the firm, including on social-psychological factors, drives candidate selection - and elite reproduction.

Natural or quasi-experiments show that socio-economic resources and security enhance noncognitive skills. Experimentally-induced scarcity reduces the capacity for self-control, with negative effects on cognitive test performance, with effects greater for those who experienced scarcity long-term (Mullainathan \& Shafir, 2013). Reductions in poverty at the community and individual level are associated with a greater sense of self-efficacy, and capacity for behavioral control (Haushofer \& Fehr, 2014; Leventhal \& Brooks-Gunn, 2003). Indeed, sustained family income security and reduced income inequality, in a US natural experiment with unconditional, universal cash payments, led to substantial positive improvement in many measures of children's non-cognitive skills - especially for those who previously had lower levels of them (Akee et al., 2015).

Lab-based experiments also support character as something deeply embodied from childhood, and constitutive of social class (Stephens et al., 2014). Working-class people, responding to vignettes, are more likely explain events in terms of features of the external environment, rather than features of the individual (Kraus et al., 2009). Expressions of self-esteem, positive and negative, not only vary by social class - they are interpreted differently depending on a person's class (as well as gender) (Shariff et al., 2012). Strangers observing a person's nonverbal behaviors for only one minute correctly estimate their socio-economic status (Kraus $\&$ Keltner, 2009). Such findings suggest it is wrong to assume the effect of self-concept, or assessments of their self-control, works independently of class.

\section{Natural effects: A macro-level model of character as cultural capital}

Despite support from experimental and ethnographic research, the idea of character as part of a classed, and gendered, cultural capital has not been well-translated or incorporated into studies that can speak to the macro, or population level. Quantitative approaches unavoidably involve some loss of theoretical and experiential nuance, but new modeling approaches can better represent class reproduction as a compound, categorical process.

Sociologists have long used survey-based measures of social-psychological as well as cognitive skills. However, they have not properly tested for the factor structure or principal components of the various measures. Standard psychometrics tests for latent unidimensional factors do not allow sub-factors to correlate with each other, poorly representing the relation between constructs (Revelle, 2019). Sociologists have also long modeled socio-economic attainment as a categorical process, in contrast to economic models of the continuous, linear intergenerational association, and producing and comparing estimates of social immobility (Erikson \& Goldthorpe, 2010; Xie, 1992). However, the analysis of the mechanisms or mediators have largely assumed linearity. Methods for estimating mediation have advanced since they developed, with structural equation or path models of status attainment (Bollen \& Pearl, 2013). Integrated into a counterfactual model of causality, the two-stage regression, g-estimation, recognizes factors that may confound the relationship between a mediator and an outcome (Acharya et al., 2016; Imai et al., 2010; Vansteelandt \& Joffe, 2014). But this approach still 
rests on the strong assumption of the independence of alternative mechanisms or skills, and that all effects are essentially linear.

New approaches to factor analysis, and mediation, better allow us to quantify character as a cultural capital, a multipart mechanism in an asymmetric attainment process. 'Omega hierarchical' is a model-based approach to factor analysis can better test the assumption of the independence and unidimensionality of different variables, by allowing subfactors to correlate. 'Natural effect' models can flexibly accommodate joint mediators, interactions between mediators, exposures and covariates, and non-linear outcomes, by not making assumptions about the density of mediators, or the generalizability of average effects on the linear scale (Lange et al., 2012; Loeys et al., 2013). They recognize that the non-collapsibility of the odd-ratio means that direct effects - the conditional association between an exposure and an categorical outcome, will typically differ from total effects, the effect in models without mediators, even if there is no indirect effect through the mediator(s) (Greenland et al., 1999). To rich data, I apply these techniques to ask what 'character' comprises, and how and for whom it contributes to social immobility.

\section{Data}

The British Cohort Study (BCS) is a nationally representative survey that offers detailed information on a range of measures of character and cognitive intelligence tests, from childhood, for a cohort recently reaching occupational maturity. The BCS sampled all children born in the United Kingdom in one week in 1970, with a $98 \%$ response rate $(\mathrm{N}=17,196)$ (Elliott \& Shepherd, 2006), and surveyed the mothers in the first year of life, and at age 5. At age 10, two-thirds of the cohort members were tested for intelligence and surveyed on their self-beliefs, and their teachers were also surveyed on their self-control behaviors, giving a substantial sample for measuring the range of skills $(\mathrm{N}=11,433)$. Almost $66 \%$ of these cohort members completed survey questions at age 34,38 and/or 42 on their occupation $(\mathrm{N}=7,420)$. Missingness on other variables is minimal, allowing me to use a complete analytic sample of $\mathrm{N}=7,345$.

\section{What does Character or the non-cognitive comprise?}

\section{Measures}

I use the full set of the most common measures of non-cognitive skills when (first) available in the BCS, at age 10. It is between ages 7 and 11 that children develop the cognitive capacities to have a concept of self (Demo, 1992).

Self-control is an assessment of the child's perseverance, task-completion and attention. Children's teachers rated the child on nine individual questions as to their behavior, using on a visual analogue scale from 1 to 47 . The measure remains valid (comprehensible and predictive) in contemporary educational settings (Daly et al., 2015).

Other questions as to the child's behaviors, exclusively behavior problems, are asked of the mother, using the Rutter's Parental and Teacher's behavioral Scales (Elander \& Rutter, 1996). These behaviors are usually divided into those that are internalizing, indicating socio-emotional problems directed inwardly toward the self, and those that are externaliz- 
ing, directed outwardly towards other people. Internalising behaviors, in children, include difficulties sleeping, being solitary, tearful or seeming fearful of new situations and people. Externalising behaviors include being aggressive, irritable, fidgety or restless.

Self-efficacy is the child's perception of her or his ability to control his life outcomes. It is measured through children's agreement with statements such as "it is not worth trying hard because things never work out anyway" (Nowicki and Strickland 1973). Several questions pertain specifically to the school setting, for example, "studying for tests is waste of time". High self-efficacy, on this measure, is general, and broadly synonymous with self-mastery and an internal locus of control, though it emphasizes efficacy in education. efficacy.

Self-esteem is the child's perception of her or his worthiness, individual value or confidence, measured by $\neg$ their agreement with statements such as "there are lots of things about myself I would like to change" (Lawrence 1981). While some self-esteem scales directly invite comparison with peers, this scale does not. Several questions reference relationships with peers, teachers and parents.

For cognitive skill I use the British Ability Scales (BAS). This standardized test has verbal as well as nonverbal elements (Elliott, Murray, \& Pearson, 1978). It is considered an ageappropriate, unbiased measure of intelligence (Hill 2005).

All measures are mean-standardized. Table 1 provides descriptive data for these measures, and those used in the subsequent analysis.

\section{Models}

To see how these measures of skill, both non-cognitive and cognitive, relate, I conduct a hierarchical factor analysis that allows factors to correlate. McDonald's omega compares the variance in a set of measures that is associated with a common factor with the variance associated with subfactors. Unlike Cronbach's alpha often used to test the uni-dimensionality of scales, it is model-based (I use minimal residuals given the relatively small number of measures) and psychometricians show it produces more reliable and conservative estimates (Revelle 2019).

This model finds against the assumptions of a single general factor or latent dimension of noncognitive skill, and of a strong divide between non-cognitive and cognitive skill dimensions. For all skill measures, the ratio of the total variance explained by a general factor to that explained by subfactors - the Explained Common Variance (ECV) - is only 0.32. Without cognitive ability, the ECV for non-cognitive factors is 0.35 . That is, one could predict an individual's relative standing on a latent variable of character based on any specific measure accurately in a third of attempts. This non-cognitive factor model, shown at the top of Figure 1 , also finds that problem behaviors form a distinct subfactor, with internalizing behaviors not correlated at all with a general dimension of skill. Excluding these behavioral problems, and including cognitive skill, the Explained Common Variance is substantially higher, at 0.65. In this model, shown at the bottom of Figure 1, self-efficacy and self-esteem form a sub-factor we can call self-concept. The teacher's assessment of behaviors indicating self-control is its own subfactor that is as correlated with a general latent factor of skills as cognitive skill. Empirically as well as theoretically then, we have reason to consider self-concept and selfcontrol two major dimensions of the 'non-cognitive', that are far from orthogonal to cognitive skill. 
Table 1: Descriptive Data for Analytic Sample

\begin{tabular}{l}
\hline Characteristic \\
\hline Female \\
Ethnic Minority \\
Unknown \\
Paternal Class \\
Unskilled \\
Partly Skilled \\
Skilled Manual \\
Skilled Non-Manual \\
Managerial \\
Professional \\
Unknown \\
Class Destination \\
Unskilled \\
Partially Skilled \\
Skilled Manual \\
Skilled Non-Manual \\
Lower Managerial and Professional \\
Higher Managerial and Professional \\
Skill Measures ${ }^{1}$ \\
Self-Control \\
Unknown \\
Self-Efficacy \\
Unknown \\
Self-Esteem \\
Unknown \\
Externalising behaviors (R) \\
Unknown \\
Internalising behaviors (R) \\
Unknown \\
Cognitive Skill \\
\hline
\end{tabular}

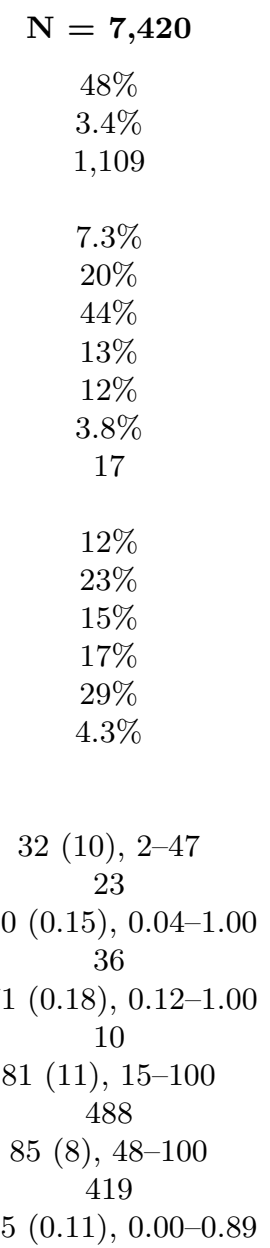

$1 \%$; Mean (SD), 0\%-100\%

$(\mathrm{R})=$ reversed so a high score is low in negative behaviors;

Note: The analytic sample is all those given cognitive tests and surveys on skills at age 10, and having class destination information, see main text.

As shown in Figure 2, the class gradient in teacher-assessed self-control is steeper than for self-concept. It also varies more by gender, with the average girl with professional parents scoring almost a full standard deviation higher in self-control than the average boy whose father worked unskilled jobs. However, the class gradient in self-esteem and efficacy, which track closely, is also significant for boys and girls. These descriptive findings indicate that we should consider two main, distinct elements of character in children - self-concept and self-control - and their relationship to cognitive skill. They recommend considering them not as a linear factor in attainment, conditional on background, but as joint mechanism of social immobility. 
Figure 1: Omega Factor Models for Character Skills

\section{With Behaviours, Without Cognitive Skill}

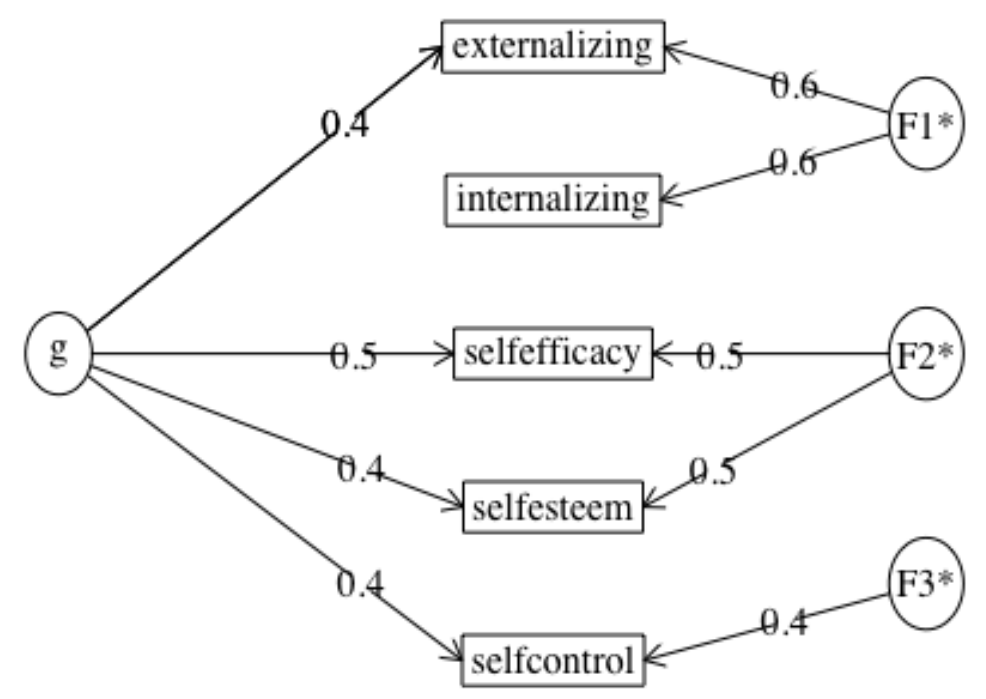

\section{Without Behaviours, With Cognitive Skill}

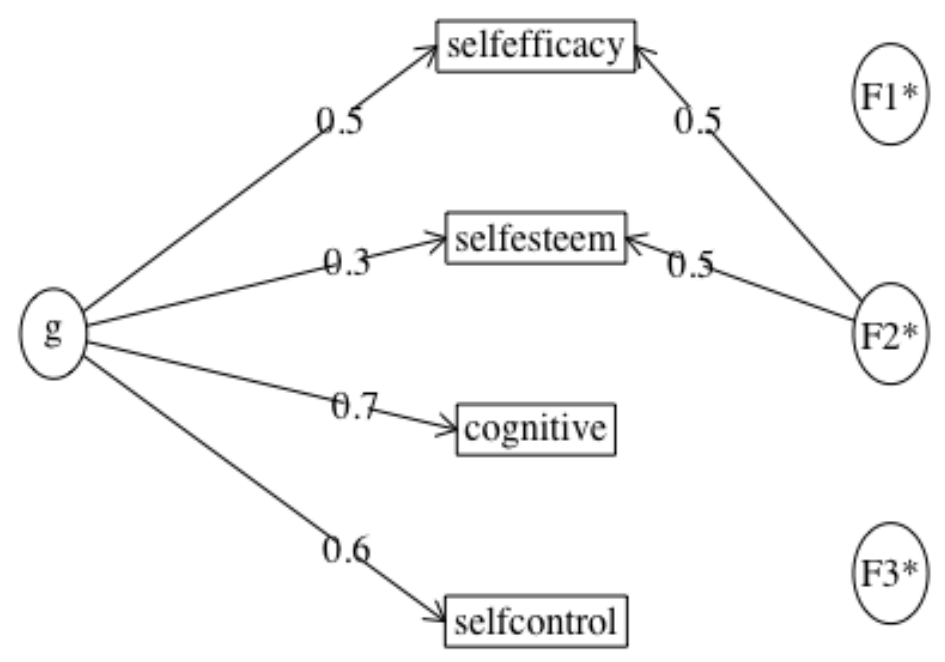


Figure 2: Self-Measures at age 10, by Class Origin and Gender

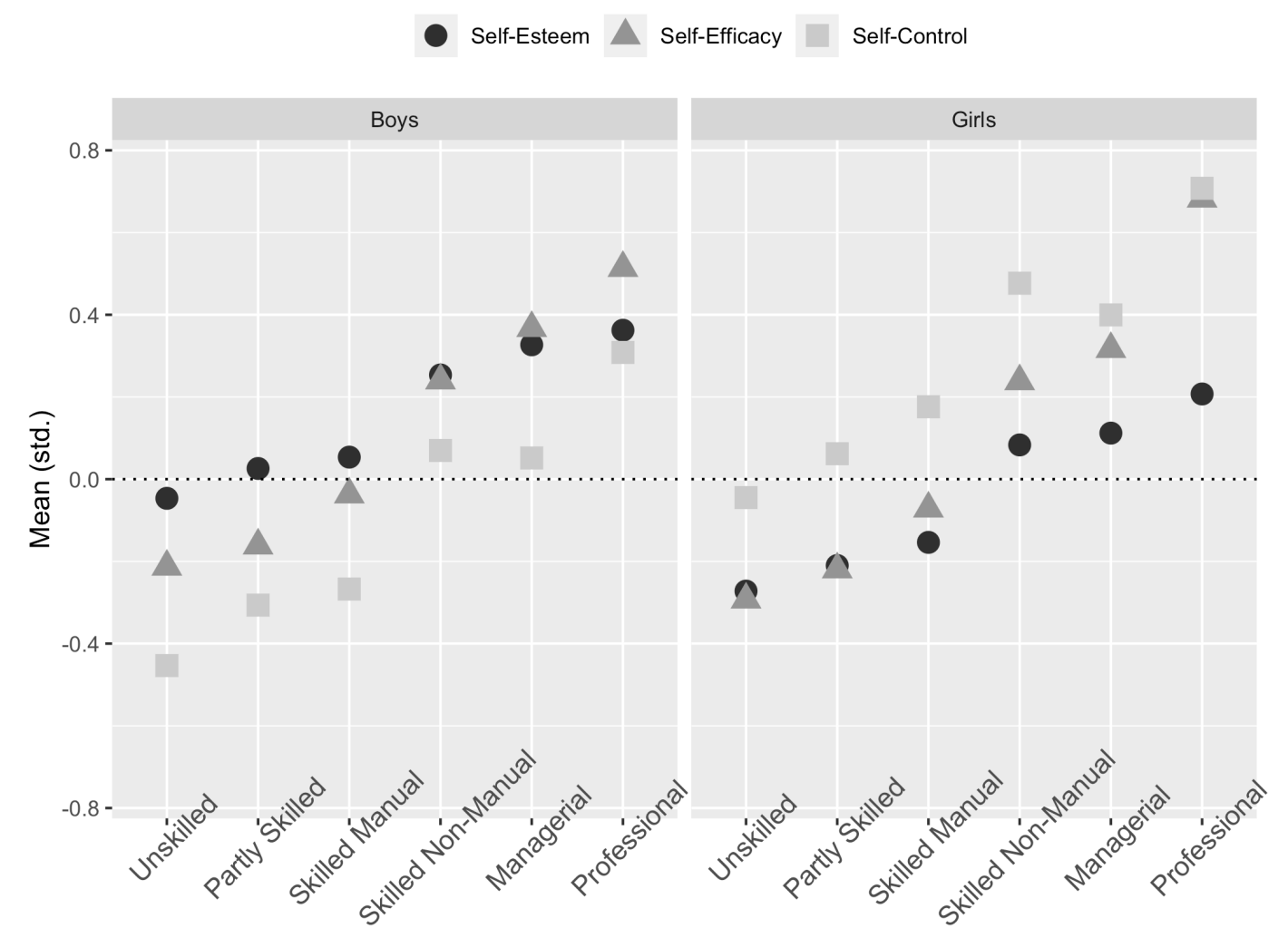

Social Class Origin 


\title{
How and for Whom Does Character Account for Social Immobility?
}

\begin{abstract}
Measures
Class origin is measured by the father's occupation in early childhood, categorized per the Erickson-Goldthorpe Portocarero (EGP) class schema. This groups occupations into the unskilled, partially skilled, manual skilled, non-manual skilled, managerial, and professional. The schema was designed to capture categorical differences in the employment relationship, the security, authority and autonomy people have at work. The major distinction it makes is between a working class, combining the bottom three classes, and a salariat or managerial and professional class (PMC), and I use these binary categorizations (Goldthorpe 2016) . In the working class, employment relationships are governed by a direct labor contract, in which employees supply discrete amounts of labor, under supervision, in return for wages. In the salariat, employment relationships a longer-term and exchange is generally more diffuse (Erikson and Goldthorpe 2002). These macro occupational classes relate consistently to education and wealth, across cohorts (Chan and Boliver 2013).
\end{abstract}

Class Destination is measured at age 42 or, if unavailable, ages 34 or 38 , when occupational maturity is reached. I use the same schema as for class origin, with one exception. Reflecting the expansion of the professional-managerial classes and their increasing overlap, higher managerial and professional occupations are distinguished from lower ones. Reflecting the UK government's classifications, the higher occupations are both higher paid and higher status, and include those managing large rather than small companies, and working as doctors, lawyers, and in finance, rather than, for example, education.

Figure 3 visualizes a class mobility contingency table for the association between class origins and destinations for this cohort, who entered the labor market in the 2000s. It reflects the decline in manual skilled jobs over this period. It also confirms the high degree of social reproduction exhibited in particular by the higher professional-managerial class in the UK, even as lower managerial and professional jobs expanded toward the end of the twentieth century (Laurison \& Friedman, 2016). As noted in Table 1, 30\% of cohort members attained the professional-managerial class, compared to $15 \%$ of their fathers. However, only $4 \%$ of the fathers were professionals, and only $4 \%$ of cohort members were in higher professionalmanagerial classes.

\section{Models}

Natural effects models relax the assumptions of the independence of mediators, and of essentially linear relationships between exposures, other characteristics, mediators, and outcomes. Preliminary statistical tests confirm the importance of this. Bartlett tests finds that the variance of self-control is not homogenous by class origins, and that neither the variance in self-esteem nor self-control is homogenous by gender. Brant tests for proportional odds find that the assumption of proportional odds, that effects of mediators and covariates are the same for attaining any ordered class destination does not hold. Natural effect models estimate total, direct and natural effects on a non-linear scale - log-odds or, exponentiated, odd-ratios - rather than collapsing these, and biasing estimates. Furthermore, they can estimate these effects for multiple, joint mediators, rather than assuming their (sequential) independence. This means, though, that rather than testing for "the" effect of character on attainment, we 
Figure 3: Class Destinations by Class Origins

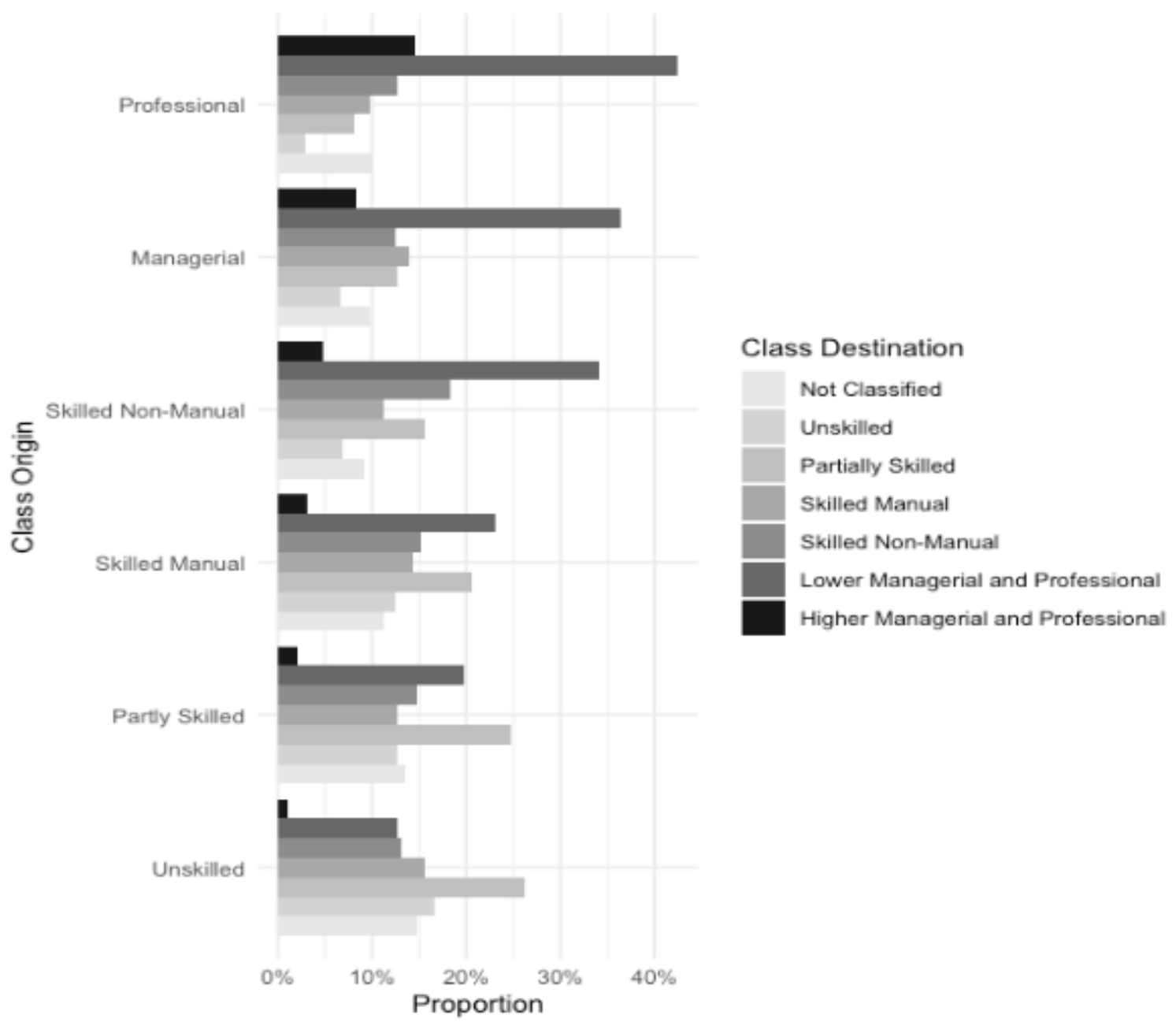

have to compare multiple models as to how (under which assumptions or conditions), and for whom (which social groups) it does so.

Natural effects are most easily interpreted with binary variables. Therefore, I estimate binomial models for three major class distinctions: (1) the effect of a working-class origin on attaining the middle class, (2) the effect of a working-class origin on attaining the professionalmanagerial class (PMC), and (3) the effect of any non-professional managerial origins on the attainment of the higher professional-managerial class. In all models, class origin, and mediators, are interacted with gender. For each mobility model, I estimate, with bootstrapped standard errors, the indirect, mediation effect of self-concept and self-control, separately and jointly, and with and without conditioning on cognitive skill. I also consider the mediation role of self-concept conditional on both self-control and cognitive skill.

\section{Attaining the middle class}

The first set of models are for the relative chances, or odds, of attaining any middle-class occupation, coming from the working-class as opposed to any other class. They are shown 
for males in Figure 4, and for females in Figure 5. The natural total effect (NTE) shows that working-class girls had about half the odds of middle-class girls of attaining the middle class, and working-class boys about two-fifths of the odds. The natural direct effect (NDE) shows that if childhood skills were at levels observed in middle class children, a working-class origin still substantially decreases the relative odds of attaining a middle-class occupation. The natural indirect effect (NIE) indicates that if working-class children had the levels of self-control and self-concept observed among middle-class children, the negative effect of a working-class origin on attaining the middle class would be reduced by about $13 \%$, to 0.6 and 0.5 the odds for females and males respectively.

Conditional on cognitive skill, however, the mediation effect for self-control is much diminished, particularly for males. For males, moving from working class to middle-class levels of self-control, without changing levels of cognitive skill, increases the odds of attaining the middle class by less than 0.05 log-odds. The mediation of effect for self-concept, however, remains meaningful conditional on cognitive scores, accounting for about $6 \%$ of the total effect of working-class origin for males, and $16 \%$ of that for females. For females, self-concept substantially mediated the effect of working-class origin on class destination conditional on both self-control and cognitive skill, accounting for $14 \%$ of the total effect. Self-concept's mediation effect remains significant net of self-control for males and females, and, for females, net of self-control and cognitive skill.

\section{Attaining the professional-managerial class}

The second set of models, summarized in Figures 6 and 7, are for the chances of attaining the professional-managerial class (PMC), for males and females respectively. The natural total effects show working-class males had a third of the odds of attaining the PMC as their middle-class counterparts and working-class females roughly half the odds. The natural direct effects estimate that if men had working-class origins, but as boys had levels of self-control and self-concept observed among middle-class boys, their chances of attaining the PMC would rise to 0.45 of middle-class males' chances. For working-class females, holding middle-class levels of self-concept and control would raise the chances of attaining the PMC substantially, to 0.79 of middle-class females' chances.

Conditional on cognitive skill, however, the natural total effect of class origin on PMC destination is roughly halved for females, more so than for males, for whom cognitive ability reduces the natural effect of class origin by less than a third. Nonetheless, child self-concept and control remain significant net mediators. Self-control accounts for approximately $10 \%$ of the controlled direct effect of working-class origin on the odds of professional-managerial destination for females, and $7 \%$ for males. Self-concept accounts for approximately $16 \%$ of the direct effect of working-class origin on a professional-managerial destination for females, and $6 \%$ for males. For males and females, self-concept remains a significant mediator conditional on self-control, but conditional on self-control and cognitive skill, mediation effects are small, lowering the effect of working-class origin on class attainment by, at the upper-bound, 0.05 log-odds.

\section{Attaining the higher professional-managerial class}

The final set of models, summarized in Figures 7 and 8, are for the odds of attaining the higher professional-managerial class, the top $4 \%$ of the occupation structure, as opposed to 
Figure 4: Natural Effects of Working Class Origin on Middle Class Destination (Odds-Ratios), Males

Self-Control

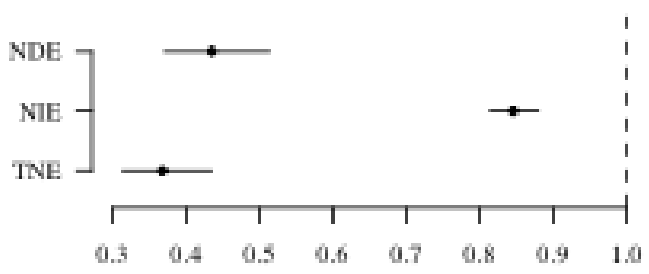

Self-Concept

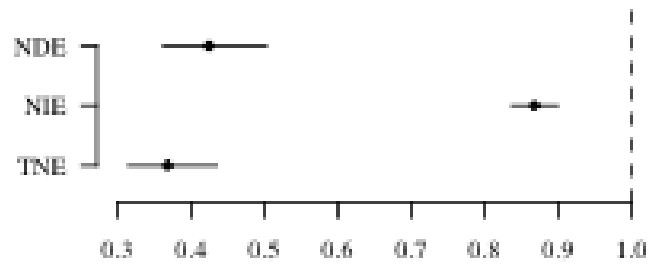

Self-Control \& Concept

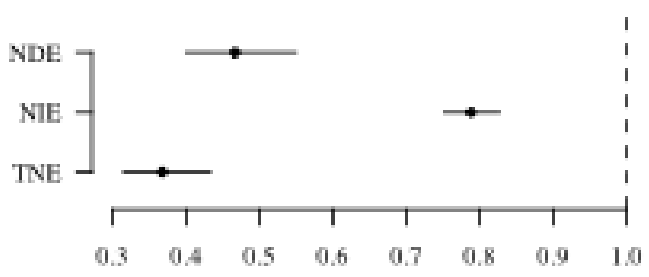

Self-Concept I Control

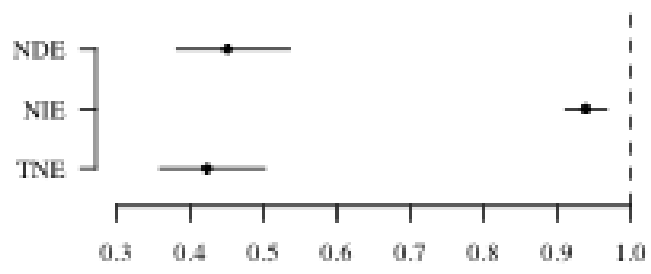

Self-Control I Cognitive

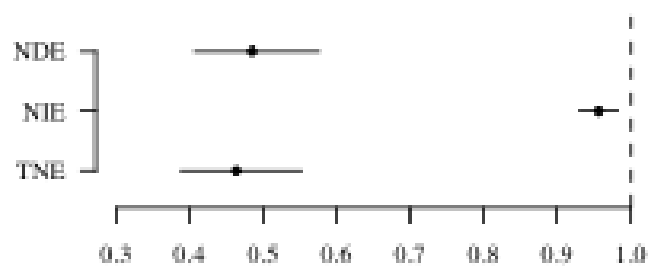

Self-Concept I Cognitive

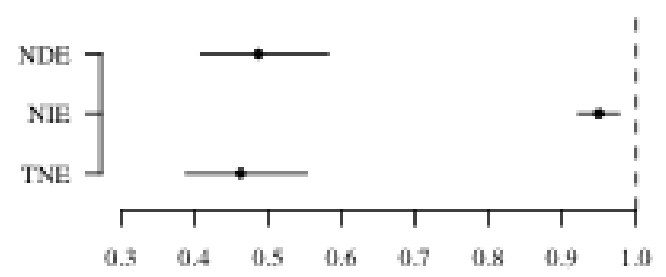

Self-Control \& Concept I Cognitive

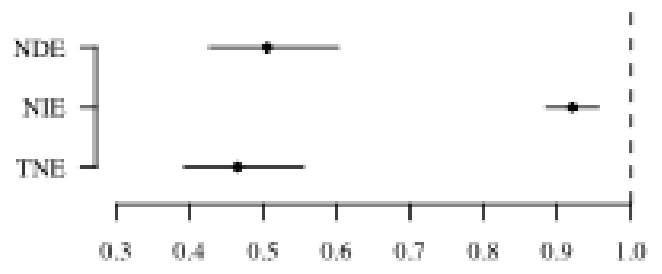

Self-Concept I Control \& Cognitive

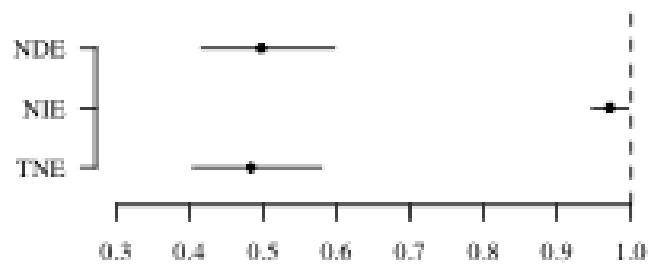

any other class, for male and females respectively. The natural total effects show that any non-professional or managerial class origin (the bottom 85\%) is associated with roughly half the odds of attaining the highest class for females, and a third of the odds for males. For males and females, the natural indirect effects through self-control and self-concept are similar, indicating that if those of professional middle class origin had working class character, their relative chances of attaining the higher PMC would be reduced by, at most, a factor of 0.75 . As a proportion of the total natural effect of class origin, character matters more for females than males. However, as the conditional models show, this reflects that cognitive ability accounts more for elite reproduction for females. In fact, for females the total or direct effects of class origin conditional on cognitive skill or self-control cannot be precisely estimated. Still, 
Figure 5: Natural Effects of Working Class Origin on Middle Class Destination (Odds-Ratios), Females

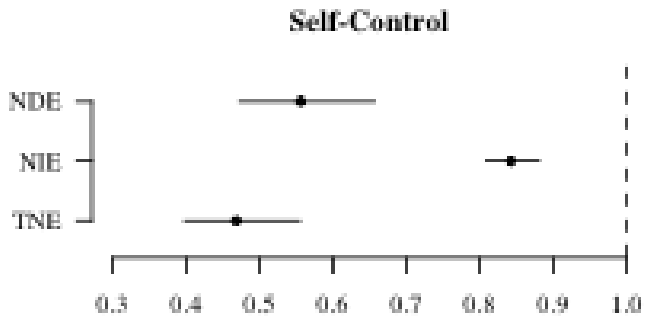

Self-Concept

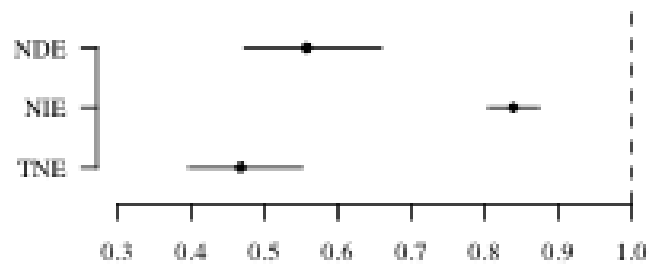

Self-Control \& Concept

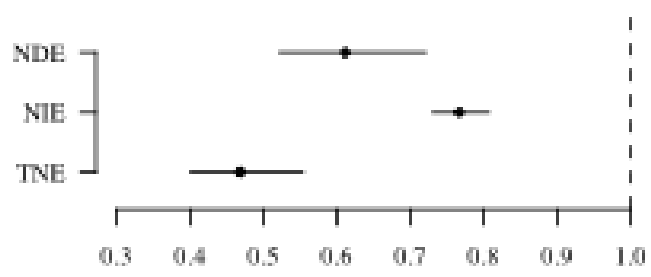

Self-Concept I Control

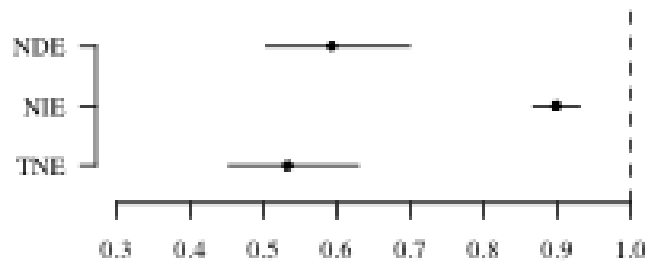

Self-Control I Cognitive

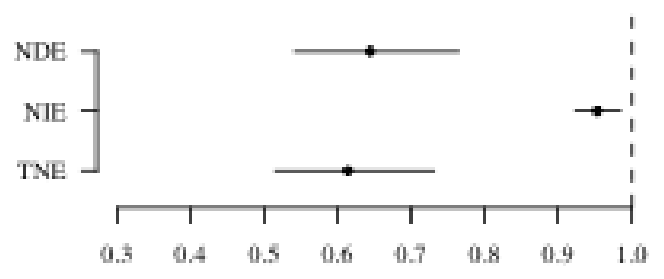

Self-Concept I Cognitive

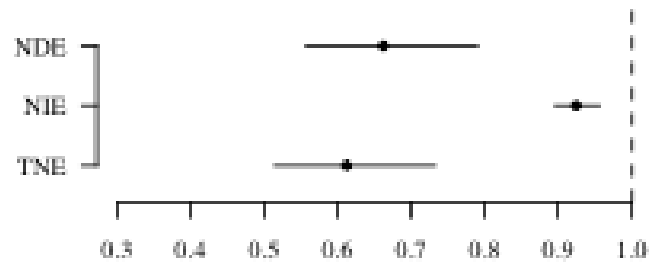

Self-Control \& Concept I Cognitive

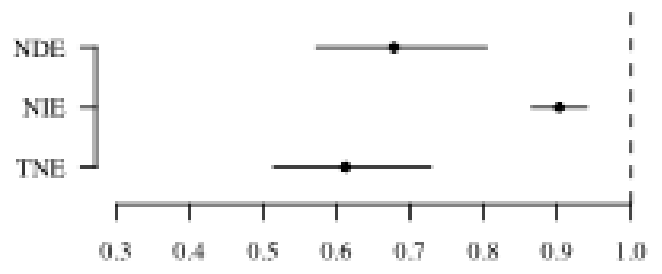

Self-Concept I Control \& Cognitive

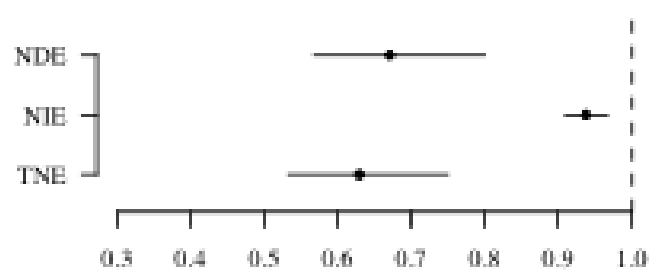

the indirect effects suggest that self-concept plays some role in elite class reproduction, even net of self-control and cognitive skill. 
Figure 6: Natural Effects of Working Class Origin on Professional-Middle Class Destination (Odds-Ratios), Males

Self-Control

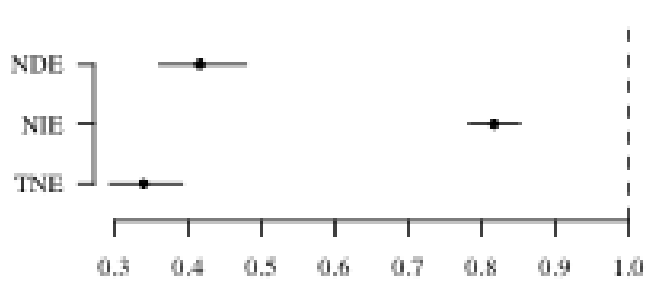

Self-Concept

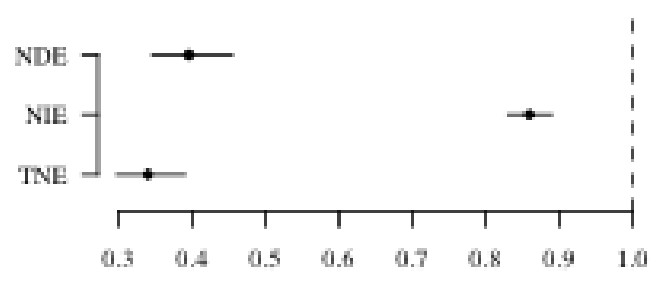

Self-Control \& Concept

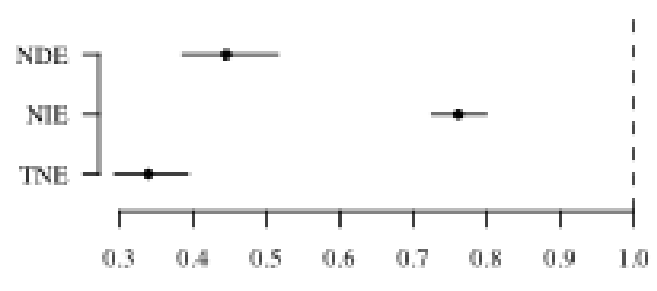

Self-Concept I Control

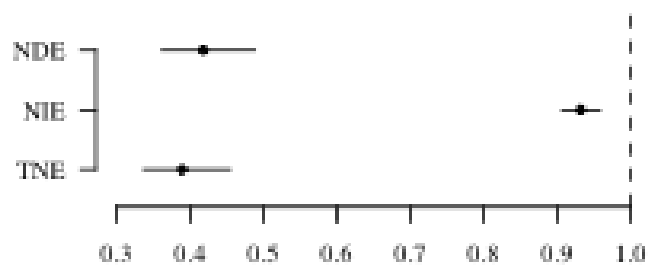

Self-Control I Cognitive

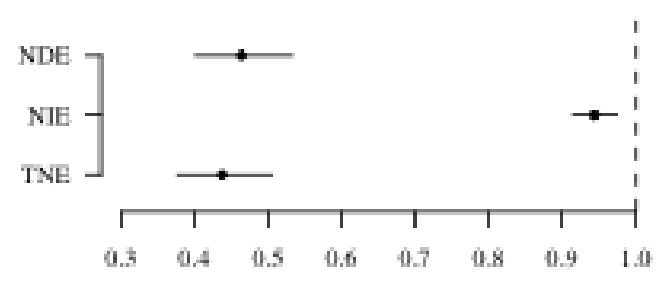

Self-Concept I Cognitive

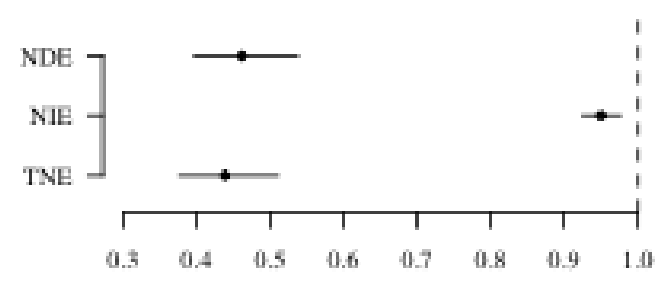

Self-Control \& Concept I Cognitive

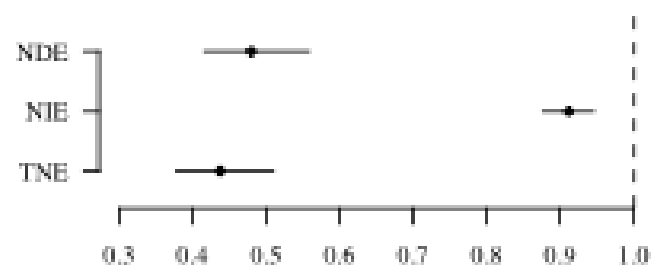

Self-Concept I Control \& Cognitive

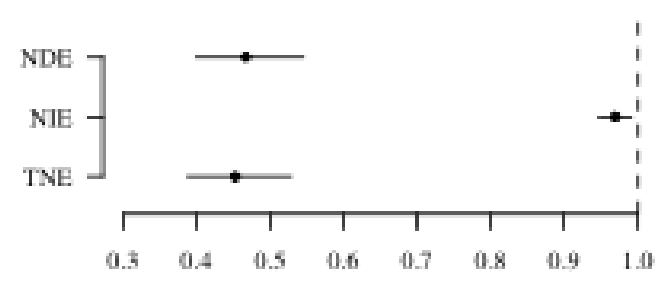


Figure 7: Natural Effects of Working Class Origin on Professional-Middle Class Destination (Odds-Ratios), Females

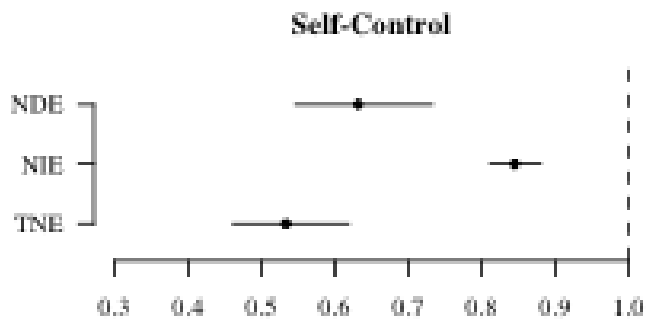

Self-Concept

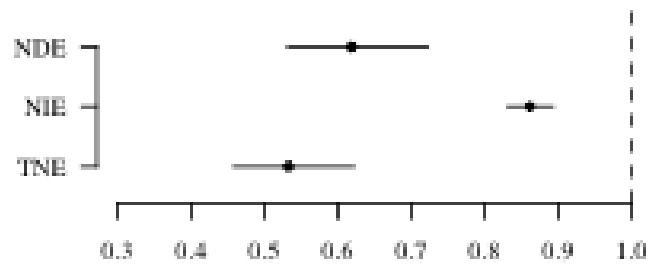

Self-Control \& Concept

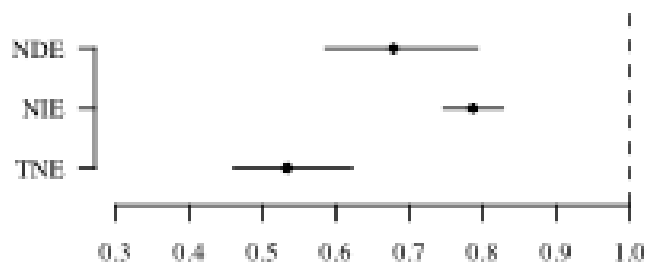

Self-Concept I Control

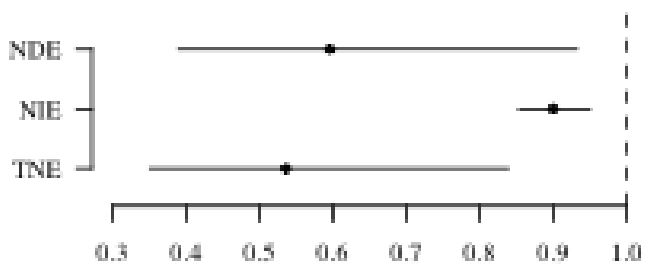

Self-Control I Cognitive

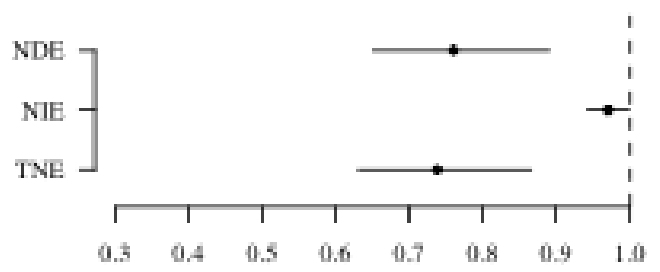

Self-Concept I Cognitive

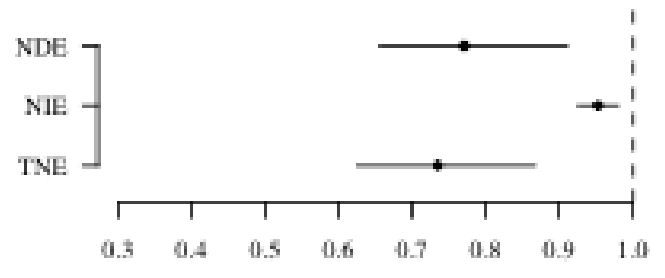

Self-Control \& Concept I Cognitive

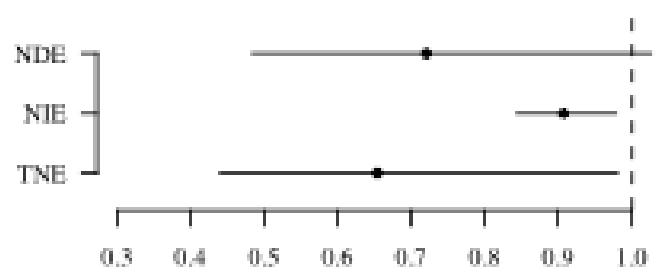

Self-Concept I Control \& Cognitive

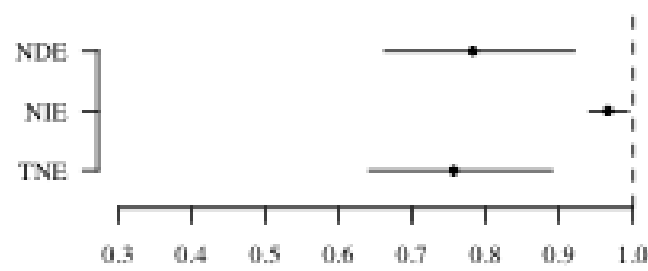


Figure 8: Natural Effects of Non-Professional Managerial Class Origin on Higher ProfessionalManagerial Class Destination (Odds-Ratios), Males

Self-Control

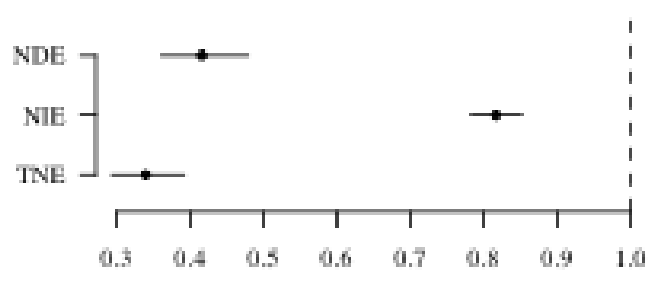

Self-Concept

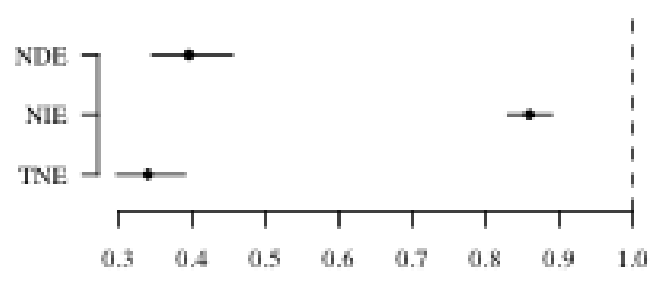

Self-Control \& Concept

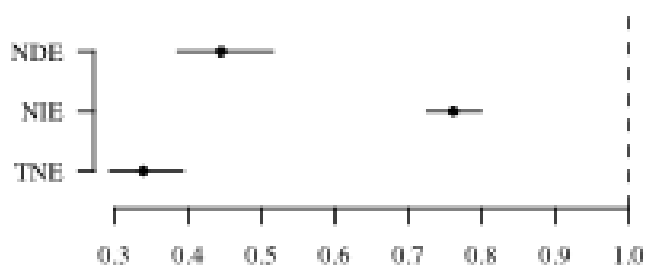

Self-Concept I Control

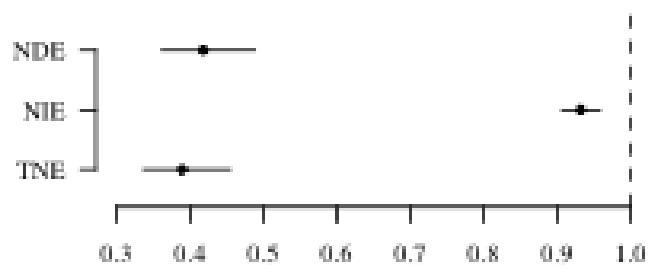

Self-Control I Cognitive

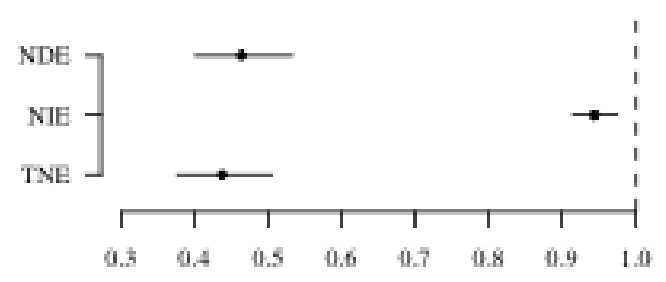

Self-Concept I Cognitive

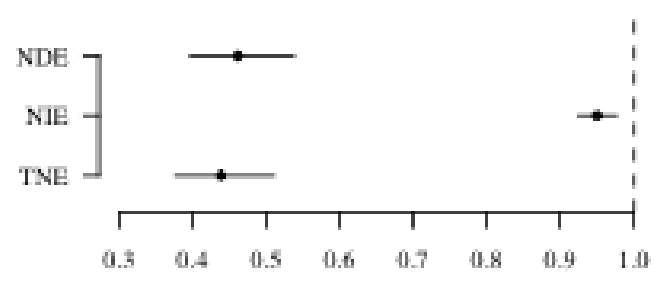

Self-Control \& Concept I Cognitive

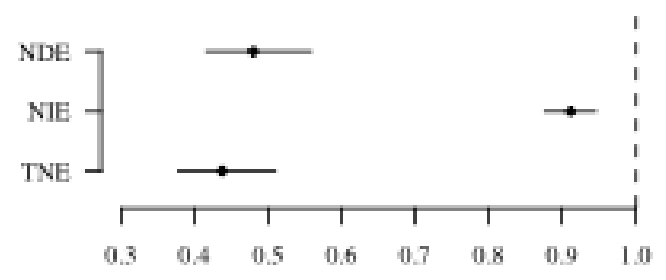

Self-Concept I Control \& Cognitive

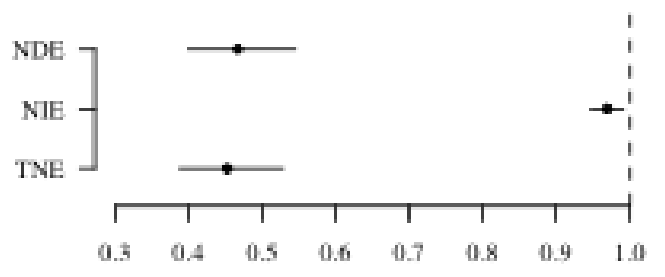


Figure 9: Natural Effects of Non-Professional Managerial Class Origin on Higher ProfessionalManagerial Class Destination (Odds-Ratios), Females

Self-Control

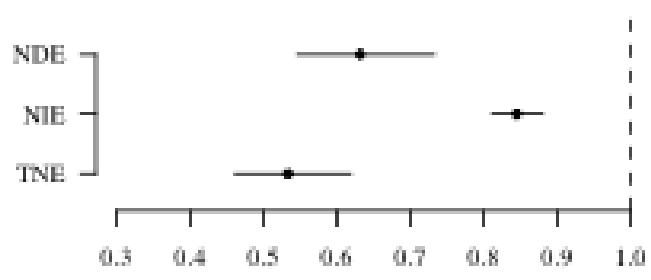

Self-Concept

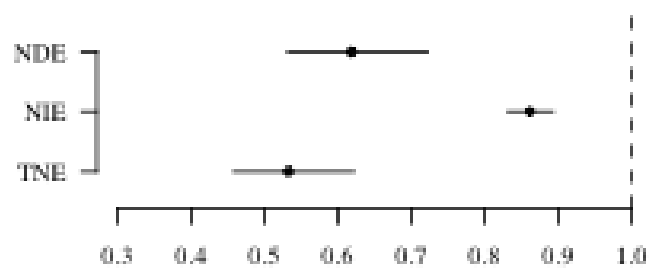

Self-Control \& Concept

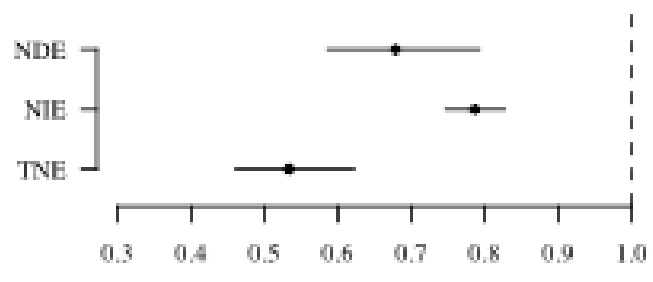

Self-Concept I Control

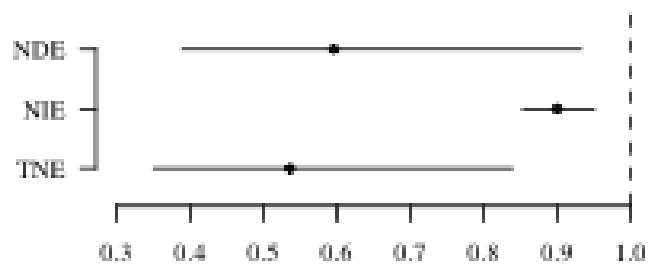

Self-Control I Cognitive

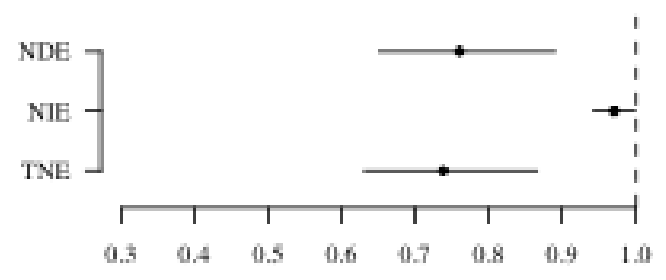

Self-Concept I Cognitive

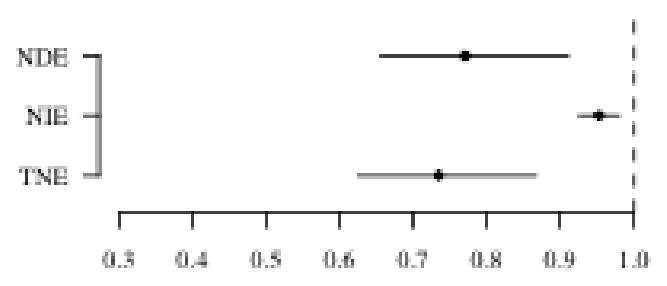

Self-Control \& Concept I Cognitive

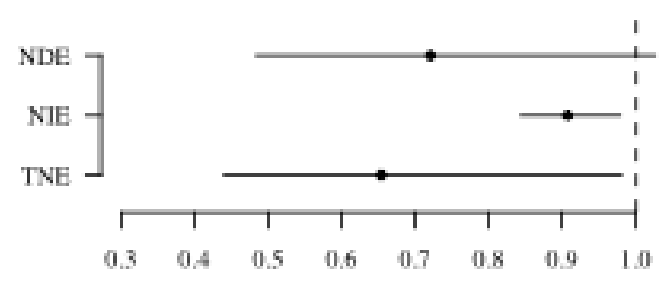

Self-Concept I Control \& Cognitive

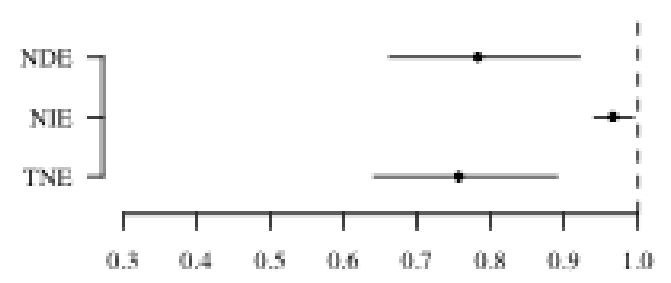




\section{Discussion}

Asking what character comprises, and how and for whom it effects attainment, this analysis finds against the two major assumptions of most studies of non-cognitive skills. First, it finds that there is no single dimension of the non-cognitive, with a behavioral self-control and subjective self-concept, principally self-efficacy or locus of control, forming two major dimensions, with the former closely correlated with cognitive test scores. Second, it finds that that there is no effect of non-cognitive skills that is independent of class background, or the class destination of concern, or assumptions about the relationship to cognitive skills.

These findings, for a nationally-representative sample, helps reconcile the conflicting findings in existing studies using different measures, samples - and model or theoretical assumptions. While self-control in particular may have little effect on socio-economic attainment conditional on cognitive skills, it likely plays a role through its relationship with cognitive skill in childhood. A substantial part of self-concept, too, likely takes effect by a reciprocal relationship with test scores. Mediation is not simply additive, with self-concept and self-control as joint mediators less than the sum of their individual mediation (indirect) effects.

Large average effects for non-cognitive skills, typically on marginal wages or non-employment, found in exclusively low-income or low education samples likely do not generalize to the population level. The effects of character on social mobility depend on class origin, gender - and the class destination. As a proportion of class origin effects net of cognitive skill, selfconcept in particular matters, for access to higher professional-managerial classes, for women. Self-control also matters to occupational attainment - as a mechanism of social immobilitywhile studies that instead look at effects conditional on social background have cast doubt on the importance of related constructs of conscientiousness or "Grit" (Credé et al., 2016; Watts et al., 2018).

This all tells us about the character, the nature, of class. The findings are consistent with studies of culture, from psychology and sociology, that emphasize culture's personal psychological level as at once cognitive, emotional and behavioral - and as an enduring aspect of class origins (Reay, 2005; Stephens et al., 2014). They are consistent with studies of economics, from economics and sociology, that indicate the value accorded to any skill reflects the character of the occupational institutions, and other characteristics of the person (Bowles et al., 2001; Vallas, 1989; Vallas \& Cummins, 2014).

Self, parental and professional assessments of non-cognitive skills are commonly used in evaluation in education, from early childhood through to university admissions, and in hiring and promotion in firms, particularly for managerial and professional roles (Illouz, 2007; Zernike, 2016). Notably, in audit studies, extracurricular activities have been used to proxy noncognitive skills, and class and gender (Protsch \& Solga, 2015; Rivera, 2015). The role character in class reproduction found here might well reflect class-based differences in the ability to know, and/or send, the appropriate signals of skills, rather than actual differences in them. The concept of cultural capital that emphasizes the difficulty, if not futility, of separating the two.

The concept of cultural capital also recognizes that character's value, as well as levels, are dynamic, and dependent on the cultural, as well as technological or macro-economic, context. We should be cautious, therefore, in generalizing these results to other contexts or cohorts. As mentioned, studies comparing this 1970 British birth-cohort with the 1958 one, find that noncognitive skills did slightly more relative to cognitive skills, to account for the intergenerational 
correlation in income between parents and adult children in the later cohort, but, in general, skills did slightly less to account for relative social mobility (Blanden et al., 2007; Breen \& Goldthorpe, 2001). An early comparison between this British cohort born in 1970 and that born in 2000 finds, as the inequalities in non-cognitive skills have increased, so too have their effects on secondary school attainment (Attanasio et al., 2020). It will be interesting to see, once this cohort reaches occupational maturity, if and how these trends affect class immobility.

For the 1970 British cohort studied here, fewer than 4.5 per cent reported a non-European ethnic identity, and net of class origin, social mobility did not vary by ethnic minority status or immigrant generation ( $\mathrm{Li}$ and Heath 2016). Analysis of more recent cohorts and settings would require attention to potential intersections with race/ethnicity. By gender, the lower social immobility, particularly in the professional-managerial classes, for women is consistent with findings from Bukodi and colleagues (2017), who show this reflects women from higherclass origins taking part-time roles in the lower-status, feminized occupations. My finding that, conditional on cognitive skill, self-concept accounts for more of the effect of class origin on destination for women than for men, echoes experimental work on women's selection out of male-dominated professions in the US (Correll, 2001). But it remains to be seen whether such patterns hold for younger cohorts and in other contexts.

The role of character in social-economic success is not only an empirical question. The use of the term character, which refers to the moral as well a mental properties of a person, in public debate about social mobility reflects this. Some sociologists have chosen to emphasize the positive self-concept that is held, and the self-control that is exercised, by working class people, as well as the social mobility that is achieved, against the odds (Seidler, 1994; Skeggs, 2004a). Nonetheless, this analysis finds that self-concept, as well as teacher-assessments of self-control, in childhood are patterned by class origins, and help account, albeit largely through performance on cognitive tests, for social immobility. In particular, a low sense of self-worth and influence over one's life, can be seen not only, as Sennett and Cobb (1993) put it, a "hidden injury" of class inequality, measurable in mid-childhood. The child's evaluation of his or her own character is an often-hidden mechanism of class reproduction.

\section{References}

Acharya, A., Blackwell, M., \& Sen, M. (2016). Explaining Causal Findings Without Bias: Detecting and Assessing Direct Effects. American Political Science Review, 110(3), $512-529$.

Akee, R. K. Q., Simeonova, E., Costello, J., Copeland, W. E., Keeler, G., Angold, A., \& Costello, E. J. (2015). Parents' Incomes and Children's Outcomes: A Quasi-Experiment Using Transfer Payments from Casino Profits. American Economic Journal: Applied Economics, 2(1), arXiv arXiv:1011.1669v3, 86-115. https://doi.org/10.1007/s13398014-0173-7.2

Anger, S., \& Schnitzlein, D. D. (2016). Cognitive skills, non-cognitive skills, and family background: evidence from sibling correlations. Journal of Population Economics, 30(2), 591-620. https://doi.org/10.1007/s00148-016-0625-9

Attanasio, O., Blundell, R., Conti, G., \& Mason, G. (2020). Inequality in socio-emotional skills: A cross-cohort comparison. Journal of Public Economics, (forthcoming). 
Bandelj, N., Wherry, F. F., \& Zelizer, V. A. (2012). Talking about Relational Work with Viviana Zelizer. https: / / orgtheory. wordpress . com / 2012 / 09 / 06 / talking - about relational-work-with-viviana-zelizer/

Blanden, J., Gregg, P., \& Macmillan, L. (2007). Accounting for Intergenerational Income Persistence: Noncognitive Skills, Ability and Education. The Economic Journal, 117(519), C43-C60. https://doi.org/10.1111/j.1468-0297.2007.02034.x

Bollen, K. A., \& Pearl, J. (2013). Eight Myths About Causality and Structural Equation Models (S. L. Morgan, Ed.). In S. L. Morgan (Ed.), Handbook of causal analysis for social research. Springer. https://doi.org/10.1007/978-94-007-6094-3

Bourdieu, P. (1987). What Makes a Social Class? On The Theoretical and Practical Existence Of Groups. Berkeley Journal of Sociology, 32(1987), 1-17. https://doi.org/10.2307/ 41035356

Bourdieu, P., \& Passeron, J. C. (1990). Reproduction in Education, Society and Culture. Sage Publications (CA). http://books.google.com/books?hl=en\%7B\%5C\&\%7Dlr=\%7B\% $5 \mathrm{C} \& \% 7 \mathrm{Did}=\mathrm{TPp} 4 \mathrm{o} 2 \mathrm{EpTK} 8 \mathrm{C} \% 7 \mathrm{~B} \% 5 \mathrm{C} \& \% 7 \mathrm{Dpgis}=1$

Bourdieu, P., \& Wacquant, L. J. D. (1992). An Invitation to Reflexive Sociology. University of Chicago Press.

Bowles, S., Gintis, H., \& Osborne, M. (2001). Incentive-Enhancing Preferences: Personality, Behavior, and Earnings. American Economic Review, 91(2), 155-158. http://www. jstor.org/stable/2677751

Breen, R., \& Goldthorpe, J. H. (1999). Class inequality and meritocracy: a critique of Saunders and an alternative analysis. The British journal of sociology, 50(1), 1-27. http://www. ncbi.nlm.nih.gov/pubmed/15266672

Breen, R., \& Goldthorpe, J. H. (2001). Class, Mobility and Merit The Experience of Two British Birth Cohorts. European Sociological Review, 17(2), 81-101. https://doi.org/ $10.1093 / \mathrm{esr} / 17.2 .81$

Breen, R. (2019). Education and intergenerational social mobility in the US and four European countries. Oxford Review of Economic Policy, 35(3), 445-466. https://doi.org/10. 1093/oxrep/grz013

Bukodi, E., Goldthorpe, J. H., Joshi, H., \& Waller, L. (2017). Why have relative rates of class mobility become more equal among women in Britain? British Journal of Sociology, 68(3), 512-532. https://doi.org/10.1111/1468-4446.12274

Calarco, J. M. (2014). Coached for the Classroom. American Sociological Review, 79(5), 10151037. https://doi.org/10.1177/0003122414546931

Correll, S. J. (2001). Gender and the Career Choice Process: The Role of Biased Self-Assessments. American Journal of Sociology, 106 (6), 1691-1730.

Credé, M., Tynan, M. C., \& Harms, P. D. (2016). Much Ado About Grit: A Meta-Analytic Synthesis of the Grit Literature. Journal of Personality and Social Psychology, 113(3), 492-511. https://doi.org/10.1037/pspp0000102

Currie, J., \& Stabile, M. (2006). Child mental health and human capital accumulation: the case of ADHD. Journal of Health Economics, 25 (6), 1094-118. https://doi.org/10. 1016/j.jhealeco.2006.03.001

Daly, M., Delaney, L., Egan, M., \& Baumeister, R. F. (2015). Childhood Self-Control and Unemployment Throughout the Life Span: Evidence From Two British Cohort Studies. Psychological Science, 26(6), 709-723. https://doi.org/10.1177/0956797615569001

de Araujo, P., \& Lagos, S. (2013). Self-esteem, education, and wages revisited. Journal of Economic Psychology, 34, 120-132. https://doi.org/10.1016/J.JOEP.2012.12.001 
Demange, P. A., Malanchini, M., Mallard, T. T., Biroli, P., Cox, S. R., Grotzinger, A. D., Tucker-Drob, E. M., Abdellaoui, A., Arseneault, L., van Bergen, E., Boomsma, D. I., Caspi, A., Corcoran, D. L., Domingue, B. W., Harris, K. M., Ip, H. F., Mitchell, C., Moffitt, T. E., Poulton, R., ... Nivard, M. G. (2021). Investigating the Genetic Architecture of noncognitive skills using GWAS-by-subtraction. Nature Genetics, 53, $35-44$.

Demo, D. H. (1992). The Self-Concept Over Time: Research Issues and Directions. Annual Review of Sociology, 18(1), 303-326. https://doi.org/10.1146/annurev.so.18.080192. 001511

DiMaggio, P. (2012). Sociological perspectives on the face-to-face enactment of class distinction. (S. T. Fiske \& H. R. Markus, Eds.). In S. T. Fiske \& H. R. Markus (Eds.), Facing social class: How societal rank influences interaction. NY, Russell Sage Foundation.

Dirks, M. A., De Los Reyes, A., Briggs-Gowan, M., Cella, D., \& Wakschlag, L. S. (2012). Embracing not erasing contextual variability in children's behavior-theory and utility in the selection and use of methods and informants in developmental psychopathology. Journal of Child Psychology and Psychiatry, 53(5), 558-74. https://doi.org/10.1111/ j.1469-7610.2012.02537.x

Duckworth, A. L., Quinn, P. D., \& Tsukayama, E. (2012). What No Child Left Behind Leaves Behind: The Roles of IQ and Self-Control in Predicting Standardized Achievement Test Scores and Report Card Grades. Journal of educational psychology, 104(2), 439451. https://doi.org/10.1037/a0026280

Duckworth, A. L., \& Seligman, M. E. P. (2012). Self-discipline outdoes IQ in predicting academic performance of adolescents. Psychological Science, 16(12), 939-944. https: //doi.org/10.1111/j.1467-9280.2005.01641.x

Duncan, G. J., Dowsett, C. J., Claessens, A., Magnuson, K., Huston, A. C., Klebanov, P., Pagani, L. S., Feinstein, L., Engel, M., Brooks-Gunn, J., Sexton, H., Duckworth, K., \& Japel, C. (2007). School readiness and later achievement. Developmental Psychology, 43(6), 1428-46. https://doi.org/10.1037/0012-1649.43.6.1428

Elander, J., \& Rutter, M. (1996). An Update on the Status of the Rutter Parents' and Teachers' Scales. Child and Adolescent Mental Health, 1(1), 31-35. https://doi.org/ 10.1111/j.1475-3588.1996.tb00006.x

Elliott, J., \& Shepherd, P. (2006). Cohort profile: 1970 British Birth Cohort (BCS70). International Journal of Epidemiology, 35(4), 836-43. https://doi.org/10.1093/ije/dyl174

Erikson, R., \& Goldthorpe, J. H. (2010). Has social mobility in Britain decreased? Reconciling divergent findings on income and class mobility. The British journal of sociology, 61 (2), 211-30. https://doi.org/10.1111/j.1468-4446.2010.01310.x

Fletcher, J. M. (2013). The effects of personality traits on adult labor market outcomes: Evidence from siblings. Journal of Economic Behavior \& Organization, 89, 122-135. https://doi.org/10.1016/j.jebo.2013.02.004

Gecas, V. (2001). The Self as a Social Force (T. J. Owens, S. Stryker, \& N. Goodman, Eds.). In T. J. Owens, S. Stryker, \& N. Goodman (Eds.), Extending self-esteem theory and research. Cambridge University Press.

Goffman, E. (1959). The Presentation of Self in Everyday Life. Doubleday.

Goldthorpe, J. H. (2016). Social class mobility in modern Britain: changing structure, constant process. Journal of the British Academy, 4(July), 89-111. https://doi.org/10.5871/ jba/004.089 
Greenland, S., Robins, J. M., \& Pearl, J. (1999). Confounding and collapsibility in causal inference. Statistical Science, 14(1), 29-46. https://doi.org/10.1214/ss/1009211805

Haushofer, J., \& Fehr, E. (2014). On the psychology of poverty. Science, 344(6186), 862-867. https://doi.org/10.1126/science.1232491

Heckman, J. J., \& Kautz, T. (2013). Fostering and Measuring Skills: Interventions That Improve Character and Cognition (tech. rep.).

Heckman, J. J., Pinto, R., \& Savelyev, P. (2014). Perry Preschool \& Character: Character skills are more important than IQ in driving better life outcomes (tech. rep.). www. heckmanequation.org

Heckman, J. J., Pinto, R., \& Savelyev, P. (2013). Understanding the Mechanisms Through Which an Influential Early Childhood Program Boosted Adult Outcomes. The American Economic Review, 103(6), 2052-2086. https://doi.org/10.1257/aer.103.6.2052

Heckman, J. J., \& Rubinstein, Y. (2001). The Importance of Noncognitive Skills: Lessons from the GED Testing Program. The American Economic Review, 91(2), 145-149. https://doi.org/10.1257/aer.91.2.145

Heckman, J. J., Stixrud, J., \& Urzua, S. (2006). The Effects of Cognitive and Noncognitive Abilities on Labor Market Outcomes and Social Behavior. Journal of Labor Economics, 24 (3), 411-482. https://doi.org/10.1086/504455

Hitlin, S., \& Johnson, M. K. (2015). Reconceptualizing Agency within the Life Course: The Power of Looking Ahead. American Journal of Sociology, 120(5), 1429-1472.

Hochschild, A. R. (1979). Emotion Work, Feeling Rules and Social Structure. American Journal of Sociology, 85(3), 551-575. http://www.jstor.org/stable/2778583

Hochschild, A. R. (2003). The Commercialization of Intimate Life: Notes from Home and Work. University of California Press.

Hsin, A., \& Xie, Y. (2017). Life Course Changes in the Mediation of Cognitive and NonCognitive Skills for Parental Effects on Children's Academic Achievement. Social Science Research, 63(March), 150-165. https://doi.org/12-755

Illouz, E. (2007). Cold Intimacies: The Making of Emotional Capitalism. Polity Press.

Imai, K., Keele, L., \& Tingley, D. (2010). A general approach to causal mediation analysis. Psychological Methods, 15(4), 309-334. https://doi.org/10.1037/a0020761

Jackson, M. (2006). Personality traits and occupational attainment. European Sociological Review, 22(2), 187-199. https://doi.org/10.1093/esr/jci051

Jackson, M., \& Grusky, D. B. (2018). A post-liberal theory of stratification. The British Journal of Sociology, 69(4), 1096-1133. https://doi.org/10.1111/1468-4446.12505

James, S. L., \& Amato, P. R. (2013). Self-Esteem and the Reproduction of Social Class. Social science quarterly, 94(4), 933-955. https://doi.org/10.1111/ssqu.12019

Joshi, H. (2014). NON-COGNITIVE' SKILLS: WHAT ARE THEY AND HOW CAN THEY BE MEASURED IN THE BRITISH COHORT STUDIES? Institute of Education: Center for Longitudinal Studies Working Paper, (September).

Kraus, M. W., \& Keltner, D. (2009). Signs of socioeconomic status: a thin-slicing approach. Psychological Science, 20(1), 99-106. https://doi.org/10.1111/j.1467-9280.2008. 02251.x

Kraus, M. W., Piff, P. K., \& Keltner, D. (2009). Social class, sense of control, and social explanation. Journal of personality and social psychology, 97(6), 992-1004. https: //doi.org/10.1037/a0016357 
Lamont, M. (2012). Toward a Comparative Sociology of Valuation and Evaluation. Annual Review of Sociology, 38(1), 201-221. https://doi.org/10.1146/annurev-soc-070308120022

Lange, T., Vansteelandt, S., \& Bekaert, M. (2012). A simple unified approach for estimating natural direct and indirect effects. American Journal of Epidemiology, 176(3), 190195. https://doi.org/10.1093/aje/kwr525

Lareau, A., \& Weininger, E. B. (2003). Cultural Capital in Educational Research: A Critical Assessment. Theory and Society, 32(5), 567-606.

Laurison, D., \& Friedman, S. (2016). The Class Pay Gap in Higher Professional and Managerial Occupations. American Sociological Review, 81(4), 668-695. https://doi.org/10. $1177 / 0003122416653602$

Leventhal, T., \& Brooks-Gunn, J. (2003). Moving to opportunity: an experimental study of neighborhood effects on mental health. American Journal of Public Health, 93(9), 1576-82. http://www.pubmedcentral.nih.gov/articlerender.fcgi?artid=1448013\%7B\% $5 \mathrm{C} \& \% 7 \mathrm{Dtool}=$ pmcentrez\%7B\%5C\&\%7Drendertype $=$ abstract

Lewis, S. K., Ross, C. E., \& Mirowsky, J. (1999). Establishing a Sense of Personal Control in the Transition to Adulthood. Social Forces, 77(4), 1573-1599. https://doi.org/10. $1093 / \mathrm{sf} / 77.4 .1573$

Loeys, T., Moerkerke, B., de Smet, O., Buysse, A., Steen, J., \& Vansteelandt, S. (2013). Flexible Mediation Analysis in the Presence of Nonlinear Relations: Beyond the Mediation Formula. Multivariate Behavioral Research, 48(6), 871-894. https://doi.org/10.1080/ 00273171.2013 .832132

Luiz Carlos Baptista, Ann Branaman, Charles Lemert, Norman K. Denzin, James J. Chriss, Uta Gerhardt, Philip Manning, Anne Warfield Rawls, Gregory W. H. Smith, Mary F. Rogers, \& Thomas J. Scheff. (2003). Goffman's Legacy (J. A. Tevino, Ed.). Rowman \& Littlefield.

Malanchini, M., Engelhardt, L. E., Grotzinger, A. D., Harden, K. P., \& Tucker-Drob, E. M. (2018). "Same But Different": Associations Between Multiple Aspects of Self-Regulation, Cognition, and Academic Abilities. Journal of Personality and Social Psychology, 117(6), 1164-1188. https://doi.org/10.1037/pspp0000224

Mazumder, B. (2015). Inequality in skills and the Great Gatsby curve. Essays on Issues: The Federal Reserve Bank of Chicago, Number 330.

McLeod, J. D., \& Fettes, D. L. (2007). Trajectories of Failure: The Educational Careers of Children with Mental Health Problems. AJS; American journal of sociology, 113(3), 653-701. https://doi.org/10.1086/521849

McLeod, J. D., \& Kaiser, K. (2004). Childhood Emotional and Behavioral Problems and Educational Attainment. American Sociological Review, 69(5), 636-658. https://doi. org/10.1177/000312240406900502

Mirowsky, J., \& Ross, C. E. (2007). Life Course Trajectories of Perceived Control and Their Relationship to Education. American Journal of Sociology, 112(5), 1339-1382. https: //doi.org/10.1086/511800

Mischel, W., Ayduk, O., Berman, M. G., Casey, B. J., Gotlib, I. H., Jonides, J., Kross, E., Teslovich, T., Wilson, N. L., Zayas, V., \& Shoda, Y. (2011). 'Willpower' over the life span: decomposing self-regulation. Social Cognitive and Affective Neuroscience, 6(2), 252-6. https://doi.org/10.1093/scan/nsq081

Moffitt, T. E., Arseneault, L., Belsky, D., Dickson, N., Hancox, R. J., Harrington, H., Houts, R., Poulton, R., Roberts, B. W., Ross, S., Sears, M. R., Thomson, W. M., \& Caspi, A. 
(2011). A gradient of childhood self-control predicts health, wealth, and public safety. Proceedings of the National Academy of Sciences of the United States of America, 108(7), 2693-8. https://doi.org/10.1073/pnas.1010076108

Moilanen, K. L., Shaw, D. S., \& Maxwell, K. L. (2010). Developmental cascades: externalizing, internalizing, and academic competence from middle childhood to early adolescence. Development and Psychopathology, 22(3), 635-53. https://doi.org/10.1017/ S0954579410000337

Morris, T. T., Davey Smith, G., van Den Berg, G., \& Davies, N. M. (2021). Consistency of Non-Cognitive Skills and their relation to educational outcomes in a UK cohort. BioRxiv. https://doi.org/https://doi.org/10.1101/470682

Mullainathan, S., \& Shafir, E. (2013). Scarcity: Why having too little means so much. Penguin Random House.

Protsch, P., \& Solga, H. (2015). How Employers Use Signals of Cognitive and Noncognitive Skills at Labour Market Entry. Insights from Field Experiments. European Sociological Review, 31 (532), 521-5. https://doi.org/10.1093/esr/jcv056

Pugh, A. J. (2013). The theoretical costs of ignoring childhood: rethinking independence, insecurity, and inequality. Theory and Society, 43(1), 71-89. https://doi.org/10. 1007/s11186-013-9209-9

Reay, D. (2005). Beyond Consciousness? The Psychic Landscape of Social Class. Sociology, 39(5), 911-928. https://doi.org/10.1177/0038038505058372

Reeves, R. (Ed.). (2014). Essays on Character and Opportunity. The Brookings Institute. http://www.brookings.edu/about/centers/ccf/character-opportunity-project

Revelle, W. (2019). The Personality Project: An introduction to psychometric theory. Springer. http://www.personality-project.org/r/book/

Rivera, L. A. (2015). Pedigree: How elite students get elite jobs. Princeton University Press.

Ross, C. E., \& Broh, B. A. (2000). The Roles of Self-Esteem and the Sense of Personal Control in the Academic Achievement Process. Sociology of Education, $73(4), 270$. https://doi.org/10.2307/2673234

Seidler, V. J. (1994). Recovering The Self: Morality and Social Theory. Routledge.

Sennett, R., \& Cobb, J. (1993). The Hidden Injuries of Class. Faber \& Faber.

Shanahan, M. J., Bauldry, S., Roberts, B. W., Macmillan, R., \& Russo, R. (2014). Personality and the Reproduction of Social Class. Social Forces, 93(1), 209-240. https://doi.org/ $10.1093 / \mathrm{sf} / \mathrm{sou} 050$

Shariff, A. F., Tracy, J. L., \& Markusoff, J. L. (2012). (Implicitly) judging a book by its cover: the power of pride and shame expressions in shaping judgments of social status. Personality 8 Social Psychology Bulletin, 38(9), 1178-93. https://doi.org/10.1177/ 0146167212446834

Skeggs, B. (2004a). Class, self, culture. Routledge.

Skeggs, B. (2004b). Exchange, value and affect: Bourdieu and 'the self'. Sociological Review, 52(s2), 75-95. http://journals.sagepub.com/doi/pdf/10.1111/j.1467-954X.2005. 00525.x

Smithers, L. G., Sawyer, A. C. P., Chittleborough, C. R., Davies, N., Smith, G. D., \& Lynch, J. (2018). A systematic review and meta-analysis of effects of early life non-cognitive skills on academic, psychosocial, cognitive and health outcomes Europe PMC Funders Group. Nat Hum Behav, 2(11), 867-880. https://doi.org/10.1038/s41562-018-0461-x 
Stephens, N. M., Markus, H. R., \& Phillips, L. T. (2014). Social class culture cycles: how three gateway contexts shape selves and fuel inequality. Annual Review of Psychology, 65, 611-34. https://doi.org/10.1146/annurev-psych-010213-115143

Tomaskovic-Devey, D., \& Avent-Holt, D. (2019). Relational Inequalities: An Organizational Appraoch. Oxford University Press.

Turney, K., \& McLanahan, S. (2015). The academic consequences of early childhood problem behaviors. Social Science Research, 54, 131-45. https://doi.org/10.1016/j.ssresearch. 2015.06.022

Twenge, J. M., \& Campbell, W. K. (2002). Self-Esteem and Socioeconomic Status: A MetaAnalytic Review. Personality and Social Psychology Review, 6(1), 59-71. https://doi. org/10.1207/S15327957PSPR0601_3

Vallas, S. P. (1989). The Concept of Skill: A Critical Review. Work and Occupations, 17(4), 379-98. http://eric.ed.gov/?id=EJ416062

Vallas, S. P., \& Cummins, E. (2014). Relational Models of Organizational Inequalities: Emerging Approaches and Conceptual Dilemmas. American Behavioral Scientist, 58(2), 228255. https://doi.org/10.1177/0002764213503327

Vansteelandt, S., \& Joffe, M. (2014). Structural Nested Models and G-estimation: The Partially Realized Promise. Statistical Science, 29(4), arXiv arXiv:1503.01589v1, 707731. https://doi.org/10.1214/14-STS493

Wacquant, L. (2016). A Concise Genealogy and Anatomy of Habitus. The Sociological Review, 64(1), 64-72. https://doi.org/10.1111/1467-954X.12356

Watts, T. W., Duncan, G. J., \& Quan, H. (2018). Revisiting the Marshmallow Test: A Conceptual Replication Investigating Links Between Early Delay of Gratification and Later Outcomes. Psychological Science, 29(7), 1159-1177. https://doi.org/10.1177/ 0956797618761661

Wharton, A. S. (2009). The Sociology of Emotional Labor. Annual Review of Sociology, 35(1), 147-165. https://doi.org/10.1146/annurev-soc-070308-115944

Xie, Y. (1992). The Log-Multiplicative Layer Effect Model for Comparing Mobility Tables. American Sociological Review, 57(3), 380. https://doi.org/10.2307/2096242

Xie, Y., Near, C., Xu, H., \& Song, X. (2020). Heterogeneous treatment effects on Children's cognitive/non-cognitive skills: A reevaluation of an influential early childhood intervention. Social Science Research, 86. https://doi.org/10.1016/j.ssresearch.2019.102389

Yeager, D. S., Hanselman, P., Walton, G. M., Murray, J. S., Crosnoe, R., Muller, C., Tipton, E., Schneider, B., Hulleman, C. S., Hinojosa, C. P., Paunesku, D., Romero, C., Flint, K., Roberts, A., Trott, J., Iachan, R., Buontempo, J., Yang, S. M., Carvalho, C. M., ... Dweck, C. S. (2019). A national experiment reveals where a growth mindset improves achievement. Nature, 573(7774), 364-369. https://doi.org/10.17605/OSF.IO/ MD2QA

Zelizer, V. A. (2012). How I became a relational economic sociologist and what does that mean? Politics and Society, 47(2006), 1-31.

Zernike, K. (2016). Testing for Joy and Grit? Nationwide Push to Measure Students' Emotional Skills.

Dissertation.bib 


\section{Appendix}

Table 1: Itemization of Self-Control and Self-Concept Measures

\begin{tabular}{ll}
\hline & Self-Control \\
\cline { 1 - 1 } Cronbach's & 0.92 \\
alpha & \\
Inter-item r & 0.57 \\
Scoring & $1-47$ visual scale
\end{tabular}

Items Child is daydreaming $(\mathrm{R})$

Cannot concentrate on particular task (R)

Becomes bored during class

Shows perseverance

Easily distracted (R)

Pays attention in class

Forgetful on complex tasks (R)

Completes tasks

Fails to finish tasks (R)

\section{Self-Esteem}

0.69

0.14

No (0),

Don't Know (0.5),

Yes (1)

Parents like to hear about my ideas

Often feel lonely at school (R)

R) Others fall out with you (R)

Like team games

Others say nasty things about you (R)

Feel shy in front of teacher $(\mathrm{R})$
Feel sad because no-one to play with $(\mathrm{R})$

Lots of things about self would change $(\mathrm{R})$

Feel foolish/uneasy speaking to teacher ( $\mathrm{R}$ )

Feel foolish in front of peers (

Feel foolish talking to

parents $(\mathrm{R})$

Often have to find new

friends $(\mathrm{R})$

Others think you tell lies $(\mathrm{R})$

\section{Self-Efficacy}

0.51

0.074

No (0),

Don't Know (0.5), Yes (1)

Most of the time it is not worth trying hard because things never turn out right anyway ( $\mathrm{R}$ )

Wishing can make good things happen

People good to you no matter how you act toward them It's almost useless to try in school (R)

A high mark is a matter of luck for you (R)

Often blamed for things that aren't your fault (R)

R) The kind of person who believes planning ahead makes things turn out well Find it easy to get up in the morning When bad things to you, it is usually someone else's fault (R) If someone is very angry with you, it is impossible to make friends again $(\mathrm{R})$

When nice things happen to you it is only good luck $(\mathrm{R})$ When you get into an argument, it is usually the other person's fault (R) Studying for tests is waste of time $(\mathrm{R})$

Note: (R) indicates item reverse-coded such that high score equals high self-control, esteem or efficacy. 
Table 2: Descriptive Data by Class Destination Information

\begin{tabular}{|c|c|c|c|}
\hline & $\begin{array}{l}\text { Class Info } \\
\mathrm{N}=7,420\end{array}$ & $\begin{array}{c}\text { No Class Info } \\
\mathrm{N}=4,013\end{array}$ & p-value ${ }^{2}$ \\
\hline \multicolumn{4}{|l|}{ Characteristic } \\
\hline Female & $48 \%$ & $49 \%$ & 0.2 \\
\hline Ethnic Minority & $3.4 \%$ & $5.7 \%$ & $<0.001$ \\
\hline Unknown & $1,109(15 \%)$ & $828(21 \%)$ & \\
\hline Paternal Class & & & $<0.001$ \\
\hline Unskilled & $7.3 \%$ & $11 \%$ & \\
\hline Partly Skilled & $20 \%$ & $23 \%$ & \\
\hline Skilled Manual & $44 \%$ & $44 \%$ & \\
\hline Skilled Non-Manual & $13 \%$ & $9.7 \%$ & \\
\hline Managerial & $12 \%$ & $8.8 \%$ & \\
\hline Professional & $3.8 \%$ & $2.7 \%$ & \\
\hline Unknown & 17 & 20 & \\
\hline \multicolumn{4}{|l|}{ Self-Measures $^{1}$} \\
\hline Self-Control & $32(10), 2-47$ & $29(11), 1-47$ & $<0.001$ \\
\hline Unknown & 23 & 14 & \\
\hline Self-Efficacy & $0.60(0.15), 0.04-1.00$ & $0.58(0.16), 0.12-1.00$ & $<0.001$ \\
\hline Unknown & 36 & 36 & \\
\hline Self-Esteem & $0.71(0.18), 0.12-1.00$ & $0.69(0.18), 0.08-1.00$ & $<0.001$ \\
\hline Unknown & 10 & 18 & \\
\hline Externalising Behaviours & $81(11), 15-100$ & $79(13), 8-100$ & $<0.001$ \\
\hline Unknown & 488 & 424 & \\
\hline Internalising Behaviours & $85(8), 48-100$ & $85(9), 11-100$ & 0.13 \\
\hline Unknown & 419 & 356 & \\
\hline Cognitive Skill & $0.55(0.11), 0.00-0.89$ & $0.51(0.12), 0.00-0.85$ & $<0.001$ \\
\hline
\end{tabular}

${ }^{1}$ Mean (SD), $0 \%-100 \%$
${ }^{2}$ Pearson's Chi-squared test; Wilcoxon rank sum test 
Table 3: Brant Test for Proportional Odds, Model for Class Destination

\begin{tabular}{lrrl}
\cline { 1 - 3 } & \multicolumn{1}{c}{ X2 } & df & probability \\
\cline { 1 - 2 } Omnibus & 848.656 & 55 & 0 \\
Self-Esteem & 17.337 & 5 & 0.004 \\
Self-Efficacy & 27.684 & 5 & 0.00004 \\
Self-Control & 16.501 & 5 & 0.006 \\
Cognitive Ability & 50.729 & 5 & 0 \\
Class Origin (ref. Unskilled) & & & \\
Partly Skilled & 7.696 & 5 & 0.174 \\
Skilled Manual & 9.410 & 5 & 0.094 \\
Skilled Non-Manual & 13.941 & 5 & 0.016 \\
Managerial & 15.309 & 5 & 0.009 \\
Professional & 11.893 & 5 & 0.036 \\
Ethnic Minority & 33.120 & 5 & 0.00000 \\
Female & 448.985 & 5 & 0
\end{tabular}


Table 4: Effect Decomposition for Working Class Origin on Middle Class Destination, Males

\begin{tabular}{|c|c|c|c|c|}
\hline Mediator & Estimate & Std. Error & $z$ value & $\operatorname{Pr}(>|z|)$ \\
\hline $\begin{array}{l}\text { Control } \\
\text { natural direct effect } \\
\text { natural indirect effect } \\
\text { total effect }\end{array}$ & $\begin{array}{l}-0.831 \\
-0.168 \\
-0.999\end{array}$ & $\begin{array}{l}0.082 \\
0.020 \\
0.084\end{array}$ & $\begin{array}{r}-10.079 \\
-8.490 \\
-11.903\end{array}$ & $\begin{array}{l}0.000 \\
0.000 \\
0.000\end{array}$ \\
\hline $\begin{array}{l}\text { Control | Cognitive } \\
\text { natural direct effect } \\
\text { natural indirect effect } \\
\text { total effect }\end{array}$ & $\begin{array}{l}-0.724 \\
-0.045 \\
-0.769\end{array}$ & $\begin{array}{l}0.089 \\
0.014 \\
0.091\end{array}$ & $\begin{array}{l}-8.150 \\
-3.170 \\
-8.491\end{array}$ & $\begin{array}{l}0.000 \\
0.002 \\
0.000\end{array}$ \\
\hline $\begin{array}{l}\text { Concept } \\
\text { natural direct effect } \\
\text { natural indirect effect } \\
\text { total effect }\end{array}$ & $\begin{array}{l}-0.857 \\
-0.142 \\
-0.999\end{array}$ & $\begin{array}{l}0.084 \\
0.018 \\
0.083\end{array}$ & $\begin{array}{r}-10.199 \\
-7.706 \\
-11.973\end{array}$ & $\begin{array}{l}0.000 \\
0.000 \\
0.000\end{array}$ \\
\hline $\begin{array}{l}\text { Concept | Cognitive } \\
\text { natural direct effect } \\
\text { natural indirect effect } \\
\text { total effect }\end{array}$ & $\begin{array}{l}-0.720 \\
-0.051 \\
-0.772\end{array}$ & $\begin{array}{l}0.091 \\
0.015 \\
0.091\end{array}$ & $\begin{array}{l}-7.950 \\
-3.477 \\
-8.514\end{array}$ & $\begin{array}{l}0.000 \\
0.001 \\
0.000\end{array}$ \\
\hline $\begin{array}{l}\text { Concept \& Control } \\
\text { natural direct effect } \\
\text { natural indirect effect } \\
\text { total effect }\end{array}$ & $\begin{array}{l}-0.761 \\
-0.238 \\
-0.999\end{array}$ & $\begin{array}{l}0.082 \\
0.024 \\
0.082\end{array}$ & $\begin{array}{r}-9.333 \\
-9.844 \\
-12.249\end{array}$ & $\begin{array}{l}0.000 \\
0.000 \\
0.000\end{array}$ \\
\hline $\begin{array}{l}\text { Concept \& Control } \\
\text { natural direct effect } \\
\text { natural indirect effect } \\
\text { total effect }\end{array}$ & $\begin{array}{l}\text { Cognitive } \\
-0.683 \\
-0.083 \\
-0.765\end{array}$ & $\begin{array}{l}0.088 \\
0.020 \\
0.088\end{array}$ & $\begin{array}{l}-7.774 \\
-4.207 \\
-8.689\end{array}$ & $\begin{array}{l}0.000 \\
0.000 \\
0.000\end{array}$ \\
\hline $\begin{array}{l}\text { Concept | Control } \\
\text { natural direct effect } \\
\text { natural indirect effect } \\
\text { total effect }\end{array}$ & $\begin{array}{l}-0.797 \\
-0.063 \\
-0.860\end{array}$ & $\begin{array}{l}0.086 \\
0.015 \\
0.086\end{array}$ & $\begin{array}{r}-9.257 \\
-4.267 \\
-10.040\end{array}$ & $\begin{array}{l}0.000 \\
0.000 \\
0.000\end{array}$ \\
\hline $\begin{array}{l}\text { Concept | Control \& } \\
\text { natural direct effect } \\
\text { natural indirect effect } \\
\text { total effect }\end{array}$ & $\begin{array}{l}\text { Cognitive } \\
-0.699 \\
-0.029 \\
-0.728\end{array}$ & $\begin{array}{l}0.092 \\
0.013 \\
0.092\end{array}$ & $\begin{array}{l}-7.601 \\
-2.275 \\
-7.939\end{array}$ & $\begin{array}{l}0.000 \\
0.023 \\
0.000\end{array}$ \\
\hline
\end{tabular}


Table 5: Effect Decomposition for Working Class Origin on Middle Class Destination, Females

\begin{tabular}{|c|c|c|c|c|}
\hline Mediator & Estimate & Std. Error & $z$ value & $\operatorname{Pr}(>|z|)$ \\
\hline $\begin{array}{l}\text { Control } \\
\text { natural direct effect } \\
\text { natural indirect effect } \\
\text { total effect }\end{array}$ & $\begin{array}{l}-0.586 \\
-0.171 \\
-0.758\end{array}$ & $\begin{array}{l}0.084 \\
0.022 \\
0.085\end{array}$ & $\begin{array}{l}-6.988 \\
-7.811 \\
-8.932\end{array}$ & $\begin{array}{l}0.000 \\
0.000 \\
0.000\end{array}$ \\
\hline $\begin{array}{l}\text { Control | Cognitive } \\
\text { natural direct effect } \\
\text { natural indirect effect } \\
\text { total effect }\end{array}$ & $\begin{array}{l}-0.440 \\
-0.048 \\
-0.488\end{array}$ & $\begin{array}{l}0.088 \\
0.016 \\
0.089\end{array}$ & $\begin{array}{l}-4.987 \\
-2.977 \\
-5.487\end{array}$ & $\begin{array}{l}0.000 \\
0.003 \\
0.000\end{array}$ \\
\hline $\begin{array}{l}\text { Concept } \\
\text { natural direct effect } \\
\text { natural indirect effect } \\
\text { total effect }\end{array}$ & $\begin{array}{l}-0.584 \\
-0.176 \\
-0.760\end{array}$ & $\begin{array}{l}0.085 \\
0.021 \\
0.084\end{array}$ & $\begin{array}{l}-6.905 \\
-8.429 \\
-9.035\end{array}$ & $\begin{array}{l}0.000 \\
0.000 \\
0.000\end{array}$ \\
\hline $\begin{array}{l}\text { Concept | Cognitive } \\
\text { natural direct effect } \\
\text { natural indirect effect } \\
\text { total effect }\end{array}$ & $\begin{array}{l}-0.412 \\
-0.079 \\
-0.491\end{array}$ & $\begin{array}{l}0.089 \\
0.017 \\
0.090\end{array}$ & $\begin{array}{l}-4.618 \\
-4.697 \\
-5.440\end{array}$ & $\begin{array}{l}0.000 \\
0.000 \\
0.000\end{array}$ \\
\hline $\begin{array}{l}\text { Concept \& Control } \\
\text { natural direct effect } \\
\text { natural indirect effect } \\
\text { total effect }\end{array}$ & $\begin{array}{l}-0.492 \\
-0.266 \\
-0.758\end{array}$ & $\begin{array}{l}0.082 \\
0.025 \\
0.083\end{array}$ & $\begin{array}{r}-5.979 \\
-10.549 \\
-9.140\end{array}$ & $\begin{array}{l}0.000 \\
0.000 \\
0.000\end{array}$ \\
\hline $\begin{array}{l}\text { Concept \& Control | } \\
\text { natural direct effect } \\
\text { natural indirect effect } \\
\text { total effect }\end{array}$ & $\begin{array}{l}\text { Cognitive } \\
-0.389 \\
-0.102 \\
-0.491\end{array}$ & $\begin{array}{l}0.087 \\
0.021 \\
0.088\end{array}$ & $\begin{array}{l}-4.484 \\
-4.812 \\
-5.572\end{array}$ & $\begin{array}{l}0.000 \\
0.000 \\
0.000\end{array}$ \\
\hline $\begin{array}{l}\text { Concept | Control } \\
\text { natural direct effect } \\
\text { natural indirect effect } \\
\text { total effect }\end{array}$ & $\begin{array}{l}-0.523 \\
-0.107 \\
-0.629\end{array}$ & $\begin{array}{l}0.083 \\
0.018 \\
0.084\end{array}$ & $\begin{array}{l}-6.271 \\
-6.051 \\
-7.506\end{array}$ & $\begin{array}{l}0.000 \\
0.000 \\
0.000\end{array}$ \\
\hline $\begin{array}{l}\text { Concept | Control \& } \\
\text { natural direct effect } \\
\text { natural indirect effect } \\
\text { total effect }\end{array}$ & $\begin{array}{l}\text { Cognitive } \\
-0.399 \\
-0.064 \\
-0.463\end{array}$ & $\begin{array}{l}0.088 \\
0.016 \\
0.087\end{array}$ & $\begin{array}{l}-4.563 \\
-4.027 \\
-5.333\end{array}$ & $\begin{array}{l}0.000 \\
0.000 \\
0.000\end{array}$ \\
\hline
\end{tabular}


Table 6: Effect Decomposition for Working Class Origin on Professional-Managerial Class Destination, Males

\begin{tabular}{|c|c|c|c|c|}
\hline Mediator & Estimate & Std. Error & $z$ value & $\operatorname{Pr}(>|z|)$ \\
\hline $\begin{array}{l}\text { Control } \\
\text { natural direct effect } \\
\text { natural indirect effect } \\
\text { total effect }\end{array}$ & $\begin{array}{l}-0.877 \\
-0.202 \\
-1.080\end{array}$ & $\begin{array}{l}0.072 \\
0.021 \\
0.074\end{array}$ & $\begin{array}{r}-12.103 \\
-9.418 \\
-14.585\end{array}$ & $\begin{array}{l}0.000 \\
0.000 \\
0.000\end{array}$ \\
\hline $\begin{array}{l}\text { Control | Cognitive } \\
\text { natural direct effect } \\
\text { natural indirect effect } \\
\text { total effect }\end{array}$ & $\begin{array}{l}-0.769 \\
-0.058 \\
-0.827\end{array}$ & $\begin{array}{l}0.073 \\
0.016 \\
0.075\end{array}$ & $\begin{array}{r}-10.595 \\
-3.644 \\
-11.099\end{array}$ & $\begin{array}{l}0.000 \\
0.000 \\
0.000\end{array}$ \\
\hline $\begin{array}{l}\text { Concept } \\
\text { natural direct effect } \\
\text { natural indirect effect } \\
\text { total effect }\end{array}$ & $\begin{array}{l}-0.927 \\
-0.152 \\
-1.078\end{array}$ & $\begin{array}{l}0.070 \\
0.018 \\
0.070\end{array}$ & $\begin{array}{r}-13.303 \\
-8.401 \\
-15.482\end{array}$ & $\begin{array}{l}0.000 \\
0.000 \\
0.000\end{array}$ \\
\hline $\begin{array}{l}\text { Concept | Cognitive } \\
\text { natural direct effect } \\
\text { natural indirect effect } \\
\text { total effect }\end{array}$ & $\begin{array}{l}-0.774 \\
-0.051 \\
-0.825\end{array}$ & $\begin{array}{l}0.078 \\
0.014 \\
0.078\end{array}$ & $\begin{array}{r}-9.977 \\
-3.705 \\
-10.611\end{array}$ & $\begin{array}{l}0.000 \\
0.000 \\
0.000\end{array}$ \\
\hline $\begin{array}{l}\text { Concept \& Control } \\
\text { natural direct effect } \\
\text { natural indirect effect } \\
\text { total effect }\end{array}$ & $\begin{array}{l}-0.808 \\
-0.273 \\
-1.081\end{array}$ & $\begin{array}{l}0.074 \\
0.025 \\
0.074\end{array}$ & $\begin{array}{l}-10.984 \\
-10.917 \\
-14.524\end{array}$ & $\begin{array}{l}0.000 \\
0.000 \\
0.000\end{array}$ \\
\hline $\begin{array}{l}\text { Concept \& Control } \\
\text { natural direct effect } \\
\text { natural indirect effect } \\
\text { total effect }\end{array}$ & $\begin{array}{l}\text { Cognitive } \\
-0.735 \\
-0.093 \\
-0.828\end{array}$ & $\begin{array}{l}0.075 \\
0.019 \\
0.076\end{array}$ & $\begin{array}{r}-9.763 \\
-4.841 \\
-10.825\end{array}$ & $\begin{array}{l}0.000 \\
0.000 \\
0.000\end{array}$ \\
\hline $\begin{array}{l}\text { Concept | Control } \\
\text { natural direct effect } \\
\text { natural indirect effect } \\
\text { total effect }\end{array}$ & $\begin{array}{l}-0.872 \\
-0.071 \\
-0.943\end{array}$ & $\begin{array}{l}0.077 \\
0.014 \\
0.077\end{array}$ & $\begin{array}{r}-11.390 \\
-4.961 \\
-12.289\end{array}$ & $\begin{array}{l}0.000 \\
0.000 \\
0.000\end{array}$ \\
\hline $\begin{array}{l}\text { Concept | Control \& } \\
\text { natural direct effect } \\
\text { natural indirect effect } \\
\text { total effect }\end{array}$ & $\begin{array}{l}\text { Cognitive } \\
-0.762 \\
-0.031 \\
-0.793\end{array}$ & $\begin{array}{l}0.079 \\
0.012 \\
0.079\end{array}$ & $\begin{array}{r}-9.649 \\
-2.659 \\
-10.010\end{array}$ & $\begin{array}{l}0.000 \\
0.008 \\
0.000\end{array}$ \\
\hline
\end{tabular}


Table 7: Effect Decomposition for Working Class Origin on Professional-Managerial Class Destination, Females

\begin{tabular}{|c|c|c|c|c|}
\hline Mediator & Estimate & Std. Error & $z$ value & $\operatorname{Pr}(>|z|)$ \\
\hline $\begin{array}{l}\text { Control } \\
\text { natural direct effect } \\
\text { natural indirect effect } \\
\text { total effect }\end{array}$ & $\begin{array}{l}-0.460 \\
-0.168 \\
-0.628\end{array}$ & $\begin{array}{l}0.076 \\
0.020 \\
0.076\end{array}$ & $\begin{array}{l}-6.032 \\
-8.363 \\
-8.279\end{array}$ & $\begin{array}{l}0.000 \\
0.000 \\
0.000\end{array}$ \\
\hline $\begin{array}{l}\text { Control | Cognitive } \\
\text { natural direct effect } \\
\text { natural indirect effect } \\
\text { total effect }\end{array}$ & $\begin{array}{l}-0.274 \\
-0.030 \\
-0.304\end{array}$ & $\begin{array}{l}0.081 \\
0.015 \\
0.081\end{array}$ & $\begin{array}{l}-3.388 \\
-1.945 \\
-3.743\end{array}$ & $\begin{array}{l}0.001 \\
0.052 \\
0.000\end{array}$ \\
\hline $\begin{array}{l}\text { Concept } \\
\text { natural direct effect } \\
\text { natural indirect effect } \\
\text { total effect }\end{array}$ & $\begin{array}{l}-0.481 \\
-0.149 \\
-0.630\end{array}$ & $\begin{array}{l}0.079 \\
0.019 \\
0.078\end{array}$ & $\begin{array}{l}-6.097 \\
-7.723 \\
-8.091\end{array}$ & $\begin{array}{l}0.000 \\
0.000 \\
0.000\end{array}$ \\
\hline $\begin{array}{l}\text { Concept | Cognitive } \\
\text { natural direct effect } \\
\text { natural indirect effect } \\
\text { total effect }\end{array}$ & $\begin{array}{l}-0.260 \\
-0.048 \\
-0.308\end{array}$ & $\begin{array}{l}0.086 \\
0.015 \\
0.086\end{array}$ & $\begin{array}{l}-3.008 \\
-3.169 \\
-3.582\end{array}$ & $\begin{array}{l}0.003 \\
0.002 \\
0.000\end{array}$ \\
\hline $\begin{array}{l}\text { Concept \& Control } \\
\text { natural direct effect } \\
\text { natural indirect effect } \\
\text { total effect }\end{array}$ & $\begin{array}{l}-0.388 \\
-0.240 \\
-0.628\end{array}$ & $\begin{array}{l}0.077 \\
0.026 \\
0.079\end{array}$ & $\begin{array}{l}-5.017 \\
-9.296 \\
-7.978\end{array}$ & $\begin{array}{l}0.000 \\
0.000 \\
0.000\end{array}$ \\
\hline $\begin{array}{l}\text { Concept \& Control } \\
\text { natural direct effect } \\
\text { natural indirect effect } \\
\text { total effect }\end{array}$ & $\begin{array}{l}\text { Cognitive } \\
-0.243 \\
-0.060 \\
-0.303\end{array}$ & $\begin{array}{l}0.080 \\
0.020 \\
0.081\end{array}$ & $\begin{array}{l}-3.035 \\
-3.050 \\
-3.739\end{array}$ & $\begin{array}{l}0.002 \\
0.002 \\
0.000\end{array}$ \\
\hline $\begin{array}{l}\text { Concept } \mid \text { Control } \\
\text { natural direct effect } \\
\text { natural indirect effect } \\
\text { total effect }\end{array}$ & $\begin{array}{l}-0.403 \\
-0.078 \\
-0.481\end{array}$ & $\begin{array}{l}0.079 \\
0.016 \\
0.079\end{array}$ & $\begin{array}{l}-5.076 \\
-4.708 \\
-6.093\end{array}$ & $\begin{array}{l}0.000 \\
0.000 \\
0.000\end{array}$ \\
\hline $\begin{array}{l}\text { Concept | Control \& } \\
\text { natural direct effect } \\
\text { natural indirect effect } \\
\text { total effect }\end{array}$ & $\begin{array}{l}\text { Cognitive } \\
-0.245 \\
-0.034 \\
-0.279\end{array}$ & $\begin{array}{l}0.084 \\
0.014 \\
0.084\end{array}$ & $\begin{array}{l}-2.910 \\
-2.475 \\
-3.334\end{array}$ & $\begin{array}{l}0.004 \\
0.013 \\
0.001\end{array}$ \\
\hline
\end{tabular}


Table 8: Effect Decomposition for Non-Professional-Managerial Origin on Higher Professional-Managerial Class Destination, Males

\begin{tabular}{|c|c|c|c|c|}
\hline Mediator & Estimate & Std. Error & $z$ value & $\operatorname{Pr}(>|z|)$ \\
\hline $\begin{array}{l}\text { Control } \\
\text { natural direct effect } \\
\text { natural indirect effect } \\
\text { total effect }\end{array}$ & $\begin{array}{l}-0.544 \\
-0.148 \\
-0.693\end{array}$ & $\begin{array}{l}0.090 \\
0.022 \\
0.091\end{array}$ & $\begin{array}{l}-6.045 \\
-6.790 \\
-7.614\end{array}$ & $\begin{array}{l}0.000 \\
0.000 \\
0.000\end{array}$ \\
\hline $\begin{array}{l}\text { Control | Cognitive } \\
\text { natural direct effect } \\
\text { natural indirect effect } \\
\text { total effect }\end{array}$ & $\begin{array}{l}-0.391 \\
-0.027 \\
-0.418\end{array}$ & $\begin{array}{l}0.096 \\
0.015 \\
0.097\end{array}$ & $\begin{array}{l}-4.069 \\
-1.800 \\
-4.296\end{array}$ & $\begin{array}{l}0.000 \\
0.072 \\
0.000\end{array}$ \\
\hline $\begin{array}{l}\text { Concept } \\
\text { natural direct effect } \\
\text { natural indirect effect } \\
\text { total effect }\end{array}$ & $\begin{array}{l}-0.552 \\
-0.140 \\
-0.692\end{array}$ & $\begin{array}{l}0.095 \\
0.020 \\
0.094\end{array}$ & $\begin{array}{l}-5.812 \\
-6.891 \\
-7.346\end{array}$ & $\begin{array}{l}0.000 \\
0.000 \\
0.000\end{array}$ \\
\hline $\begin{array}{l}\text { Concept | Cognitive } \\
\text { natural direct effect } \\
\text { natural indirect effect } \\
\text { total effect }\end{array}$ & $\begin{array}{l}-0.376 \\
-0.036 \\
-0.412\end{array}$ & $\begin{array}{l}0.099 \\
0.014 \\
0.099\end{array}$ & $\begin{array}{l}-3.813 \\
-2.587 \\
-4.175\end{array}$ & $\begin{array}{l}0.000 \\
0.010 \\
0.000\end{array}$ \\
\hline $\begin{array}{l}\text { Concept \& Control } \\
\text { natural direct effect } \\
\text { natural indirect effect } \\
\text { total effect }\end{array}$ & $\begin{array}{l}-0.476 \\
-0.217 \\
-0.693\end{array}$ & $\begin{array}{l}0.091 \\
0.026 \\
0.091\end{array}$ & $\begin{array}{l}-5.228 \\
-8.262 \\
-7.607\end{array}$ & $\begin{array}{l}0.000 \\
0.000 \\
0.000\end{array}$ \\
\hline $\begin{array}{l}\text { Concept \& Control } \\
\text { natural direct effect } \\
\text { natural indirect effect } \\
\text { total effect }\end{array}$ & $\begin{array}{l}\text { Cognitive } \\
-0.363 \\
-0.053 \\
-0.416\end{array}$ & $\begin{array}{l}0.095 \\
0.019 \\
0.097\end{array}$ & $\begin{array}{l}-3.806 \\
-2.777 \\
-4.288\end{array}$ & $\begin{array}{l}0.000 \\
0.005 \\
0.000\end{array}$ \\
\hline $\begin{array}{l}\text { Concept | Control } \\
\text { natural direct effect } \\
\text { natural indirect effect } \\
\text { total effect }\end{array}$ & $\begin{array}{l}-0.498 \\
-0.070 \\
-0.569\end{array}$ & $\begin{array}{l}0.097 \\
0.016 \\
0.096\end{array}$ & $\begin{array}{l}-5.131 \\
-4.406 \\
-5.918\end{array}$ & $\begin{array}{l}0.000 \\
0.000 \\
0.000\end{array}$ \\
\hline $\begin{array}{l}\text { Concept | Control \& } \\
\text { natural direct effect } \\
\text { natural indirect effect } \\
\text { total effect }\end{array}$ & $\begin{array}{l}\text { Cognitive } \\
-0.369 \\
-0.025 \\
-0.394\end{array}$ & $\begin{array}{l}0.097 \\
0.012 \\
0.097\end{array}$ & $\begin{array}{l}-3.805 \\
-2.008 \\
-4.057\end{array}$ & $\begin{array}{l}0.000 \\
0.045 \\
0.000\end{array}$ \\
\hline
\end{tabular}


Table 9: Effect Decomposition for Non-Professional Managerial Class on Higher ProfessionalManagerial Class Destination, Females

\begin{tabular}{|c|c|c|c|c|}
\hline Mediator & Estimate & Std. Error & $z$ value & $\operatorname{Pr}(>|z|)$ \\
\hline $\begin{array}{l}\text { Control } \\
\text { natural direct effect } \\
\text { natural indirect effect } \\
\text { total effect }\end{array}$ & $\begin{array}{l}-0.585 \\
-0.106 \\
-0.692\end{array}$ & $\begin{array}{l}0.098 \\
0.019 \\
0.099\end{array}$ & $\begin{array}{l}-5.968 \\
-5.717 \\
-6.995\end{array}$ & $\begin{array}{l}0.000 \\
0.000 \\
0.000\end{array}$ \\
\hline $\begin{array}{l}\text { Control | Cognitive } \\
\text { natural direct effect } \\
\text { natural indirect effect } \\
\text { total effect }\end{array}$ & $\begin{array}{r}-0.392 \\
0.006 \\
-0.386\end{array}$ & $\begin{array}{l}0.096 \\
0.012 \\
0.097\end{array}$ & $\begin{array}{r}-4.066 \\
0.508 \\
-3.989\end{array}$ & $\begin{array}{l}0.000 \\
0.612 \\
0.000\end{array}$ \\
\hline $\begin{array}{l}\text { Concept } \\
\text { natural direct effect } \\
\text { natural indirect effect } \\
\text { total effect }\end{array}$ & $\begin{array}{l}-0.539 \\
-0.153 \\
-0.692\end{array}$ & $\begin{array}{l}0.099 \\
0.022 \\
0.098\end{array}$ & $\begin{array}{l}-5.451 \\
-6.927 \\
-7.089\end{array}$ & $\begin{array}{l}0.000 \\
0.000 \\
0.000\end{array}$ \\
\hline $\begin{array}{l}\text { Concept | Cognitive } \\
\text { natural direct effect } \\
\text { natural indirect effect } \\
\text { total effect }\end{array}$ & $\begin{array}{l}-0.342 \\
-0.050 \\
-0.392\end{array}$ & $\begin{array}{l}0.098 \\
0.017 \\
0.097\end{array}$ & $\begin{array}{l}-3.496 \\
-2.993 \\
-4.032\end{array}$ & $\begin{array}{l}0.000 \\
0.003 \\
0.000\end{array}$ \\
\hline $\begin{array}{l}\text { Concept \& Control } \\
\text { natural direct effect } \\
\text { natural indirect effect } \\
\text { total effect }\end{array}$ & $\begin{array}{l}-0.502 \\
-0.188 \\
-0.691\end{array}$ & $\begin{array}{l}0.098 \\
0.025 \\
0.099\end{array}$ & $\begin{array}{l}-5.126 \\
-7.522 \\
-7.001\end{array}$ & $\begin{array}{l}0.000 \\
0.000 \\
0.000\end{array}$ \\
\hline $\begin{array}{l}\text { Concept \& Control | } \\
\text { natural direct effect } \\
\text { natural indirect effect } \\
\text { total effect }\end{array}$ & $\begin{array}{l}\text { Cognitive } \\
-0.358 \\
-0.027 \\
-0.386\end{array}$ & $\begin{array}{l}0.097 \\
0.020 \\
0.097\end{array}$ & $\begin{array}{l}-3.710 \\
-1.404 \\
-3.997\end{array}$ & $\begin{array}{l}0.000 \\
0.160 \\
0.000\end{array}$ \\
\hline $\begin{array}{l}\text { Concept | Control } \\
\text { natural direct effect } \\
\text { natural indirect effect } \\
\text { total effect }\end{array}$ & $\begin{array}{l}-0.504 \\
-0.096 \\
-0.600\end{array}$ & $\begin{array}{l}0.101 \\
0.019 \\
0.100\end{array}$ & $\begin{array}{l}-4.978 \\
-5.075 \\
-6.014\end{array}$ & $\begin{array}{l}0.000 \\
0.000 \\
0.000\end{array}$ \\
\hline $\begin{array}{l}\text { Concept } \mid \text { Control \& } \\
\text { natural direct effect } \\
\text { natural indirect effect } \\
\text { total effect }\end{array}$ & $\begin{array}{l}\text { Cognitive } \\
-0.354 \\
-0.044 \\
-0.398\end{array}$ & $\begin{array}{l}0.098 \\
0.015 \\
0.097\end{array}$ & $\begin{array}{l}-3.609 \\
-2.870 \\
-4.096\end{array}$ & $\begin{array}{l}0.000 \\
0.004 \\
0.000\end{array}$ \\
\hline
\end{tabular}


Figure 1: Omega Factor Model of 'Character' Skills, with Personality (ECV: 0.26)

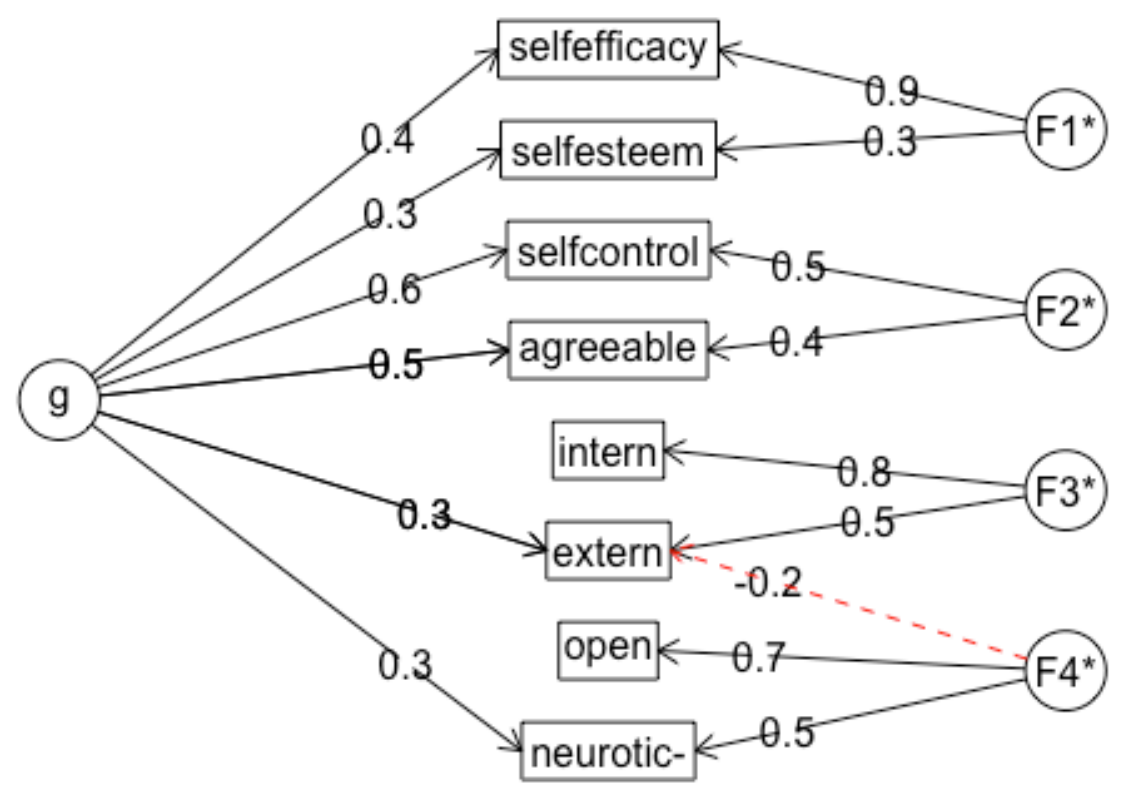

